\title{
Mardin'de İki Modern İnşa: Mardin Kışlası (1887-1891) ve Müzeye Dönüşümü (2008-2009)
}

\author{
Evrim Düzenli ${ }^{1}$ \\ ORCID: 0000-0003-0658-2403
}

\author{
Halil İbrahim Düzenli² \\ ORCID: 0000-0002-7566-5926
}

Öz

XVIII. yüzyıldan itibaren, zayıflayan Osmanlı devlet otoritesini güçlendirmek amacıla idari, ekonomik, askerlik, eğitim, vd. alanlardaki yeni örgütlenmelere bağh olarak ortaya çıkan yeni mekansal ihtiyaçlar, yeni yapı türlerinin ortaya çıkışını da beraberinde getirir. Kışlalar, bu yeni yapı türleri arasında yer alır. Bu bağlamda XIX. yüzyıl sonlarında inşa edilen Mardin Kışlası, Mardin şehri için artan merkeziyetçilikten bahsetmeye imkan tanırken, şehirde gerçekleştirilmeyi bekleyen mekansal inşaların da habercisidir. Yaklaşık bir yüzyıl sonra kışlanın müzeye dönüştürülmesi ise, şehrin de tarihselleştirilmesi suretiyle küresel kültür ekonomisine eklemlendiği ikinci bir mekansal inşa deneyimine öncülük eder. Sonuç olarak, değişen "zamansallıklar" ile beraber şehirde iki ayrı yenileşme/modernleşme biçiminin ortaya çıktığından bahsedilebilir.

Çalışmada, XIX. yüzyıl sonunda inşa edilen Mardin Kışlası ve Kışla'nın XXI. yüzyıl başlarında müzeye dönüşümü faaliyetleri üzerinden, Mardin şehrinin temas ettiğ i modernleşme deneyimleri irdelenecektir. Bu amaçla, başlangıç olarak; kısıtlı bir literatüre sahip olan yapı ile ilgili rölöve ve restorasyon projelerinden faydalanılmış, yerinde tespitler gerçekleştirilmiştir. Yapının, XIX. yüzyıl Osmanlı kışlaları içindeki konumunu belirleyebilmek amacıla bir kışla literatürü toparlanmış, müze deneyimi ise, XXI. yüzyıl müzecilik düşüncesi ve koşulları üzerinden değerlendirilmiştir. Her iki durumda elde edilen sonuçlar, şehir içindeki mekânsal karar ve örgütlenmeler, aktörler, müdahale biçim ve yöntemleri bakımından değerlendirilmesi ile şehirdeki modernleşme yaklaşımları ortaya konmaya çalışılmaktadır.

Anahtar Kelimeler: Mardin, Kışla, Müze, Osmanl, Cumhuriyet, Modernleşme

\footnotetext{
${ }^{1}$ Dr. Öğr. Üyesi., Samsun Üniversitesi, E-mail: evrim.duzenli@samsun.edu.tr

${ }^{2}$ Dr. Öğr. Üyesi, Samsun Üniversitesi, E-mail: halilibrahim.duzenli@samsun.edu.tr

idealkent @ Cent Araştırmaları Dergisi (Journal of Urban Studies) 


\title{
The Two Modern Constructions in the City of Mardin: Mardin Barracks (1887-1891) and Its Transformation into Museum (2008-2009)
}

\author{
Evrim Düzenli ${ }^{3}$ \\ ORCID: 0000-0003-0658-2403
}

\author{
Halil İbrahim Düzenli 4 \\ ORCID: 0000-0002-7566-5926
}

\begin{abstract}
Since the XVIII century, new spatial needs, emerging due to new organizations to strengthen the weakened Ottoman state authority, brings with it the emergence of new building types. Barracks are among these new building types. In this context, the Mardin Barracks, built at the end of the XIX.th century, is also a harbinger of new spatial construction attempts as an extension of a new centralization approach for the city of Mardin. Transformation of the barrack to a museum about a century later, leads to an another constructive space experience, in which the city is added to the global economy of culture. In this study, the modernization experience will be examined through both activities of constructing Mardin Barracks and its transformation to a museum. On this purpose, firstly, survey and the renovation projects of the building were mainly utilized and the on-site observations were made. Afterwards, a barrack literature was gathered in order to reveal the position of the building among the XIX.th century Ottoman barracks and the conditions of the museum and the exhibition were evaluated. The results obtained in both cases, are evaluated in terms of spatial decisions and organizations, actors, forms and methods of intervention in the city.
\end{abstract}

Keywords: Mardin, Barrack, Museum, Ottoman, Modern Turkey, Modernization

\footnotetext{
${ }^{3}$ Asts Prof., Samsun University, E-mail: evrim.duzenli@samsun.edu.tr

${ }^{4}$ Asts Prof., Samsun University, E-mail: halilibrahim.duzenli@samsun.edu.tr

idealkent @ Kent Araştırmaları Dergisi (Journal of Urban Studies) 


\section{Giriş}

XIX. yüzyılda Osmanlı'da idari, ekonomik, askerlik, eğitim, vd. alanlardaki yeni örgütlenmelere bağlı olarak ortaya çıkan yeni mekansal ihtiyaçlar, gerek kentsel ölçekte gerçekleştirilen kamusal mekan düzenlemeleri, gerekse bina ölçeğindeki uygulamaları beraberinde getirir. Bu dönem, mimarlık alanında geçmişte mevcut olmayan, yeni yapı türlerinin ortaya çıktı̆̆ı görülür. ${ }^{5} \mathrm{~K}$ şla yapıları, askerlik alanında yapılan düzenlemeler kapsamında, askerlerin barınma, eğitim, korunma ihtiyacını karşılamak amacıyla inşa edilmiş olan bu yeni yapı türleri arasında yer alır.

İstanbul'daki Kalyoncu Kışlası (1783-1784), Osmanlı'da kurulan düzenli birliklerin ihtiyacını karşılamak üzere inşa edilen ilk modern kışla binasıdır. Bununla birlikte, Kalyoncu Kışlası ve ardıllarının inşası, ağırlıklı olarak III. Selim dönemi (1789-1807) ile anılan Nizam-1 Cedid uygulamaları ve sonrasında yeniçeriliğin kaldırılması (1826), Tanzimat (1839) ve Islahat Fermanları (1856) ile kurulan yeni hukukî çerçeve, askeri müşirliklerin oluşturulması ${ }^{6}$, Asâkiri Mansûre-i Muhammediyye (1826), Redif Taburları (1834) ve doğuda Hamidiye Alayları'nın (1891) oluşturulması gibi faaliyetlerin mekansal ayaklarından birini teşkil eder.

Mardin kışlası, Kalyoncu kışlasından yaklaşık bir yüzyıl sonra 1887-1891 tarihleri arasında inşa edilir. İki inşa arasında geçen sürenin bu denli uzun oluşu birçok nedene bağlı olarak açıklanabilir. Ancak bunlardan dördü, şehrin merkez ile ilişkilerine yön vermesi açısından önemli görünüyor. Bunlardan birincisi, modernleşmenin ilk uygulamalarına karşı merkezde geliştirilen

\footnotetext{
${ }^{5}$ XIX. yüzyılda Osmanlı'da yeni yapı türleri için bkz.: Ertuğrul, 2009.

${ }^{6}$ Yeniçeri Ocağı'nın kaldırılmasından hemen sonra 1826'da çıkarılan Asakir-i Mansure-i Muhammediyye Kanunnamesi ile yine bu isimle anılan modern ve merkezi bir ordu kuruldu, ancak Osmanlı Rus Savaşı'nın etkisi, Sırp ve Yunan isyanları, Mısır'da Mehmet Ali Paşa isyanı, ekonomik sıkıntılar, askere alma yöntemlerindeki sıkıntılar gibi gerekçelerden ötürü, bu ordu, çok geniş bir coğrafyaya yayılmış olan Osmanlı Devleti'nde istenilen başarıyı gösteremedi (Çadırcı, 1980, s.66). Devlete gerekli olan askerin tamamının kışla ve karargâhlarda tutulması, devlete büyük mâli yük getirmesinin yanında, memlekette yapılan ziraî faaliyetleri de olumsuz etkileyeceğinden 1834'te Meclis-i Şura'da alınan karar ile taşrada Redif Taburları oluşturulmuştur (Çadırcı, 1980, s.66.) Redif Taburları, Anadolu'nun batı ve orta bölgeleri ile kısmen doğu Anadolu'nun bazı sancaklarında ve Rumeli'de teşkil edildi (Gedik, 2015, s.27). Redif Taburları, taşra merkezli bir örgütlenme olup İstanbul'da oluşturulmamıştır. 1936'da sancakların uygun bir biçimde birleştirilerek "müşirlik" olarak ifade edilen birimlere bağlanması ile Redif teşkilatının işleyişi iyileştirilmek istenmiştir (Çadirc1, 1980, s.70).
} 
direnç ve engellemelerin, modernleşmenin taşraya taşınımını geciktirmiş olmasıdır.7 İkinci bir neden; Osmanlı'nın taşrada, hızlı ve topyekün bir değişim gerçekleştirebilecek bir merkeziyetçilik anlayışı ve kurumsal düzenlemelerinin olmamasıdır. Taşranın merkezle arasındaki coğrafi mesafe, iletişim ve ulaşım imkanlarının kısıtlılığ ${ }^{8}$ ve yerel koşulların uygunsuzluğu diğer engellerdir. ${ }^{9}$

$\mathrm{Bu}$ bağlamda şehirde merkeziyetçiliğin kuvvetlendirilmesi, genel itibariyle bu engellerin aşılmasına dönük karar ve tedbirlerin alınarak bu minvaldeki uygulamaların gerçekleştirilmesi ile; merkez ile iletişim için gerekli teknik altyapının ${ }^{10}$ kurulması, modern örgütlenmelerin oluşturulmass ${ }^{11}$, "atamalı" aktörlerin ${ }^{12}$ etkinlikleri ve kentsel alandaki modern mimarlık uygulamaları ile yakından ilişkilidir. Mardin Kışlası, yakın çevresinde aynı dönemlerde inşa edilen Hükümet Konağı (Düzenli ve Taşar, 2012), Belediye Binası

\footnotetext{
7 Taşrada da benzer bir direnişten bahsedilebilir. 1839'da Osmanlı' nın Kavalalı Mehmet Ali Paşa'ya karşı gerçekleştirdiği Nizip Savaşı'nın yenilgiyle sonuçlanmasının, bölgede kurulmak istenen yeni düzene karşı olan kesim için fırsat yarattı̆̆ı, Avrupa menşeili her şeyin ortadan kaldırılmak istendiği ifade edilmektedir (Aydın ve diğerleri, 2000, s.01).

${ }^{8}$ Çadırcı, 19.yüzyılın başlarına gelindiğinde önemli yolların çoğu ile köprülerin bir kısmının kullanılmaz duruma düştüğünü, yılın belirli dönemleri dışında birçok bölgenin birbiriyle ve hükümet merkezleriyle irtibatının kesilmekte olduğunu, bu durumun yönetim, ekonomi ve sosyal hayatı olumsuz yönde etkilediğini ifade eder (Çadırcı, 1980, s.153).

${ }^{9}$ XIX. yüzyılda bölgede; doğuda Rusya, Mısır'da ve Suriye'de Kavalalı Mehmet Ali Paşa, Cizre ve Botan bölgesindeki Bedirhan Bey Emirliği gibi adı sık anılan muhalefet odaklarının yanı sıra, diğer beylikler, aşiretler, ayanlar gibi unsurların tamamı, çözülmesi gereken bir otorite ve asayiş problemine işaret etmektedir. Dolayısıyla Tanzimat'la getirilmek istenen yenilikler, Rusya'ya ve Mısır'da Kavalalı Mehmet Ali Paşa'ya karşı verilen mücadele, Bedirhan Bey gibi kendini bağımsız hisseden emirlik ve beyliklerin tasfiyesi, aşiretlerin yarattığı düzensizlik ve aşiretlerin iskan edilmeye çalışılması, bölgedeki ayanların etkisinin ortadan kaldırılma çabası, atamalı yöneticilerin yerel güçlere karşı verdiği mücadeleler ile iç içe girer ve Tanzimat'ın bölgede uygulama zeminin oluşması ise 1847'leri bulur (Daha fazla bilgi için bkz. Aydın ve diğerleri, 2000, s.197, 200).

${ }^{10} \mathrm{Bu}$ bağlamda gerçekleştirilmiş olan önemli faaliyetler; 1848' de başlayan Trabzon-Bağdat şosesi inşaatı, 1869 Turuk ve Meabir Nizamnamesi, 1859' da telgrafın Mardin'e ulaşmış olması, 1860'ta ülkenin ilk demiryolu hattının açılmış olmasıdır.

${ }^{11} \mathrm{Bu}$ düzenlemeler; Redif teşkilatı kuruluşu ve bağlı bulunduğu müşirliklerin belirlenmesi, 1847'de Anadolu müşirinin teklifiyle Mardin'in de içinde olduğu bir Kürdistan eyaletinin oluşturulması (Aydın ve diğerleri, 2000, s.198, 203), 1891'de Hamidiye Alayları ve bağlı bulunduğu yedi livanın belirlenmesi olarak da özetlenebilir.

12 Vali/paşalar gibi atamalı yöneticiler, XIX. yüzyıl sonunda bu valileri denetlemeye başlayan umumi müfettişler gibi modern aktörleri, taşrada merkeziyetçiliğin tesisinde önemli bir rol oynarlar.
} 
ve Kız Sanat Okulu ile birlikte, Mardin'de XIX. yüzyılda gerçekleştirilen modern-merkeziyetçi mimarlık uygulamalarından biridir. Bunların tamamı şehirde geçmişte mevcut olmayan yeni tip yapılardır ve işlevsel açıdan devlet otoritesinin şehir içindeki görünürlügü̈nü arttırırlar. Diğer taraftan Mardin şehri 2000'li yıllardan itibaren yoğun bir restorasyon ve dönüşüm faaliyetine sahne olmaktadır (Şekil 1).

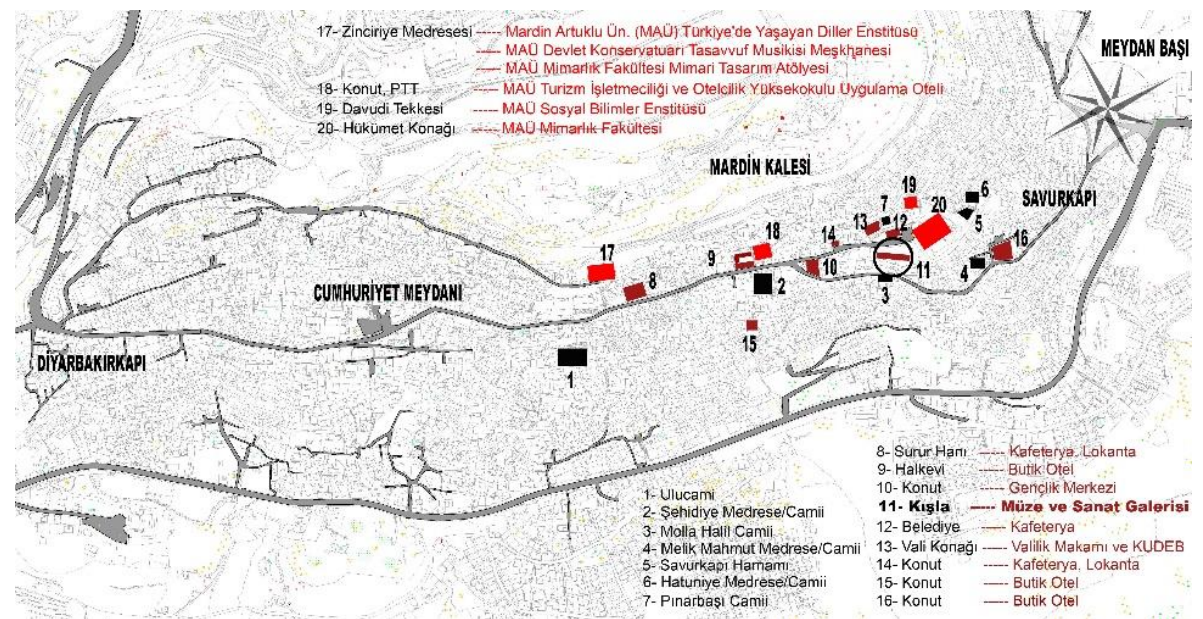

Şekil 1. Mardin anıtsal eserleri ve 2000'li yıllarda dönüştürülen yapılar

(Düzenli ve Taşar, 2012'den uyarlama)

Mardin Kışlası inşa edildikten bir yüzyıl sonra müzeye dönüşümü ile gerçekleştirilen bir başka inşa, bu sefer, şehrin küresel kültür ekonomisine eklemlenme denemelerini de temsil eden bir başka süreçten bahsetmeye imkan tanır. Mardin Kışlası 2008-2009 yılları arasında Sakıp Sabancı Mardin Kent Müzesi ve Dilek Bancı Sanat Galerisi'ne dönüştürülmüştür. Bu süreç; kışlanın müzeye dönüşümü ile başlar, çevresindeki yapıları da önüne katarak devam eder ve sonunda bir müze kent deneyimini ortaya koyan kentsel bir faaliyete dönüşür (Resim 1, 2). 

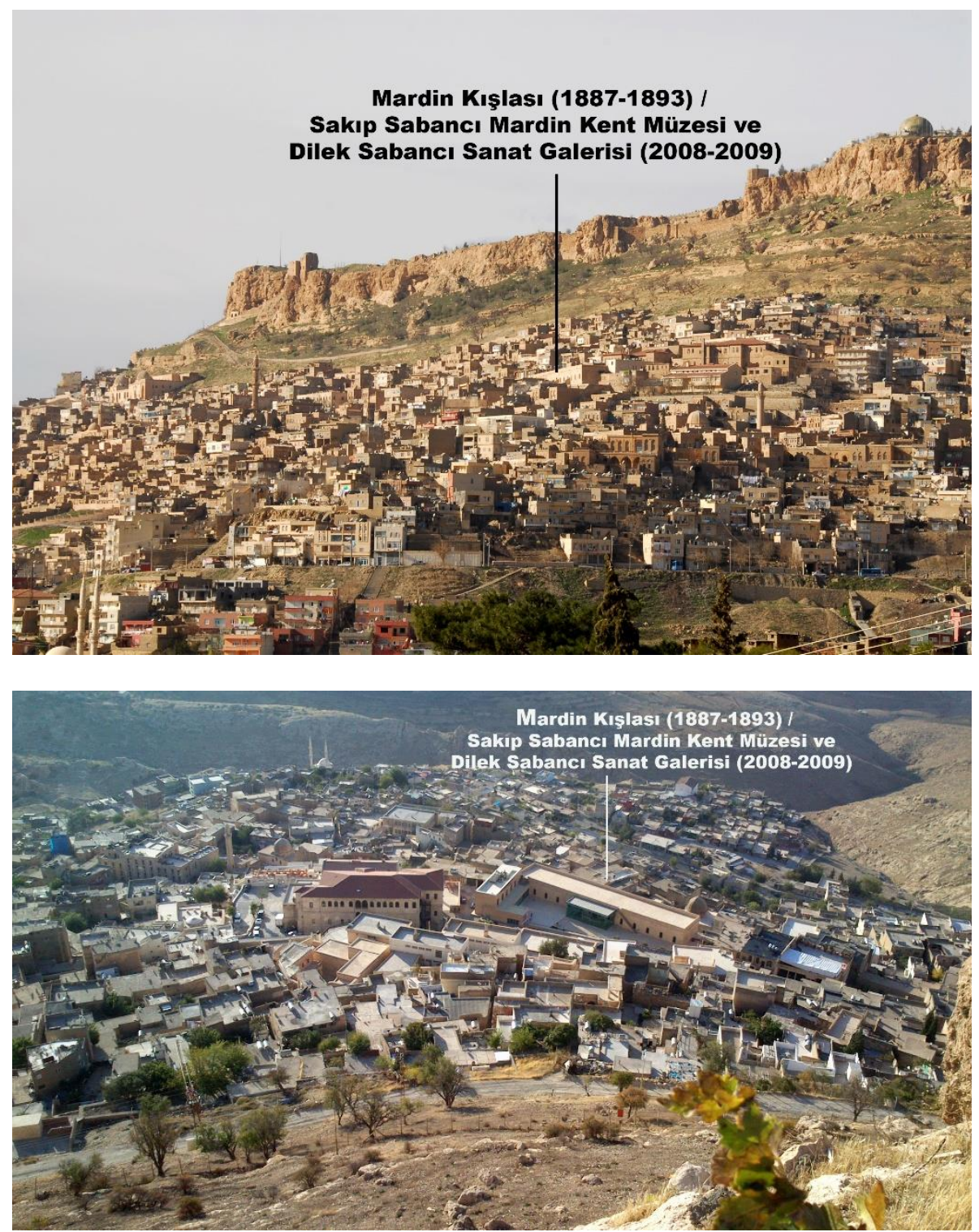

Resim 1, 2. Eski işleviyle Mardin Kışlası, yeni işleviyle Sakıp Sabancı Mardin Kent Müzesi ve Dilek Sabancı Sanat Galerisi'nin kent içindeki konumu (Fotoğraf: Halil İbrahim Düzenli)

XIX. yüzyıl sonunda inşa edilen Mardin Kışlası ve XXI. yüzyıl başlarında müzeye dönüşümü faaliyetleri ile beraber şehir, büyük ölçekli modernleşme hareketlerine sahne olmuştur. Çalışmada, şehrin modernleşme deneyimi ile temas noktaları, bu iki faaliyet üzerinden irdelenecektir. 


\section{Yüzyıl Osmanlı Kışlalanı ve Mardin Kışlası}

XIX. yüzyılda Anadolu'da inşa edilen kışla yapıları ile ilgili literatür nispeten azdır. Bu bağlamda Osmanlı'da, XVIII. ve XIX. yüzyıllarda inşa edilmiş toplam 59 adet kışla yapısının -bunların bir bölümü bugün ayakta değildir- büyük çoğunluğunu bir araya getiren en önemli kaynaklardan biri Çataltepe'nin (1997) Osmanlı arşivlerine dayandırarak hazırladığı "19.Yüzyıl Başlarında Avrupa Dengesi ve Nizam-1 Cedid" adlı kitabıdır. ${ }^{13}$ Burada yapılarla ilgili mimari bir inceleme yapılmaz, daha çok bir envanter oluşturulur ve kışlaların görsellerine yer verilmez. Çiftçi'nin (2004) "19.yüzyılda Osmanlı Devleti'nde Askeri Mimari ve İstanbul'da İnşa Edilen Askeri Yapılar" adlı doktora tezi içinde yer verdiği bir transkripsiyon, Çataltepe envanterine mimari açıdan yeni bir boyut kazandırmaktadır. Transkripsiyonda, XIX. yüzyıl sonu ve XX. yüzyıl başına ait askeri mimarlık kitaplarında yer alan teknik şartnamelere göre kışlaların nerede ve ne şekilde inşa edilmeleri gerektiğine dair bilgi verilmektedir. Burada, genel olarak; kışla yapılarının üç tip yerleşime (doğrusal, dikdörtgen veya U biçiminde) sahip olabileceği, yapıların piyade kışlası, süvari kışlası ve topçu kışlası olarak farklı işlevsel ihtiyaçları üzerinde durulmakta ve bu ihtiyaçların karşılanmasına yönelik teknik bilgiler verilmektedir. Bu bağlamda şartnamenin taşrada ne ölçüde uygulama imkanına sahip olduğu, üzerinde durulması gereken noktalar arasındadır. Nitekim tanımlı tiplerin dışında, Anadolu'da birçok farklı kışla tipinin (tekil yapı ya da kompleks biçiminde) rastlanabiliyor oluşunu, kışlanın inşa edildiği bölgedeki yerel koşulların etkisine; inşa edildiği şehrin merkezsel karakterine, stratejik konum, istihdam ettiği asker sayısı ya da barındırdığı işlev, yerel yapım tekniklerine, yapı malzemesine vd. koşullarına bağlamak mümkün görünüyor (Tablo 1).

\footnotetext{
${ }^{13}$ Bashanov ve Kemaloğlu'nun (2018: 20) “Rus Genelkurmay Belgelerinde II. Abdülhamit ve Osmanlı Ordusu" kitabında yer alan ve Osmanlı alayları ve taburlarının konuşlandığı merkezleri gösteren tablo, II. Abdülhamit döneminde, Çataltepe'nin (1997) aktardığından daha fazla sayıda kışladan bahsetmeyi mümkün kılar. Özen'in (2013) II. Mahmut dönemindeki kışla yapılarını, Çiftçi'nin (2004) XIX. yüzyılda Osmanlı Devleti'nde askeri mimariyi incelediği doktora tezi ile Aytar'ın (2016) Çimenlik Kışlası örneğinde Sultan Abdüllaziz dönemindeki kışla yapılarını ve Gedik'in (2015) Kütahya Kışlası' nı ele aldıkları tez çalışmaları, İlban'ın (2015) Sultan Abdülmecid dönemindeki kışla yapılarını ve Yazıcı'nın (2012) Samsun Kışlası örneğinde Osmanlı kışlalarını ele aldığı makaleleri Anadolu'daki kışla yapılarryla ilgili yapılmış önemli derlemelerdir.
} 
Tablo 1. Osmanlı'da XVIII. ve XIX. yüzyılda inşa edilen bazı kışlaların görünüş ve planimetrik özellikleri

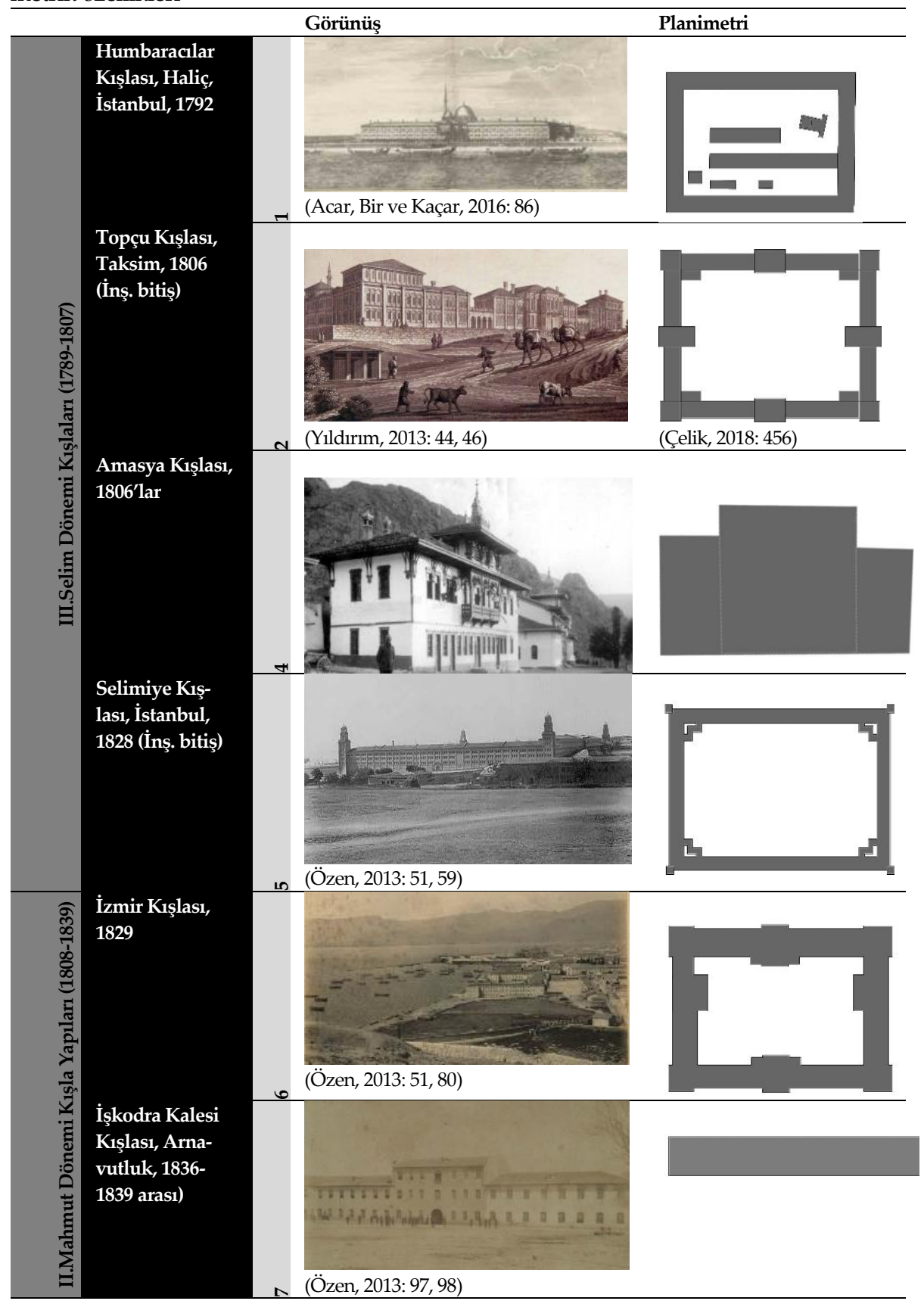




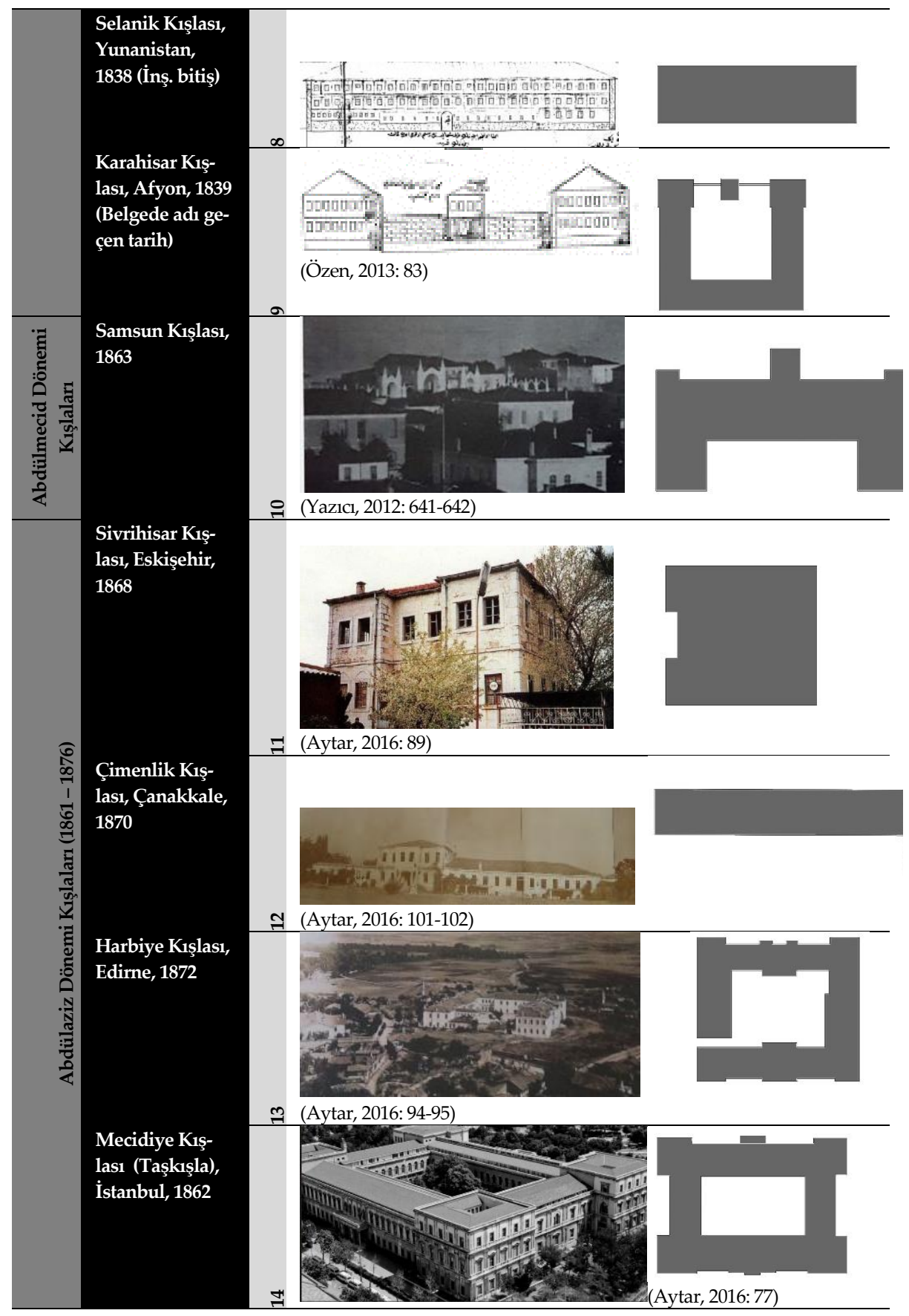




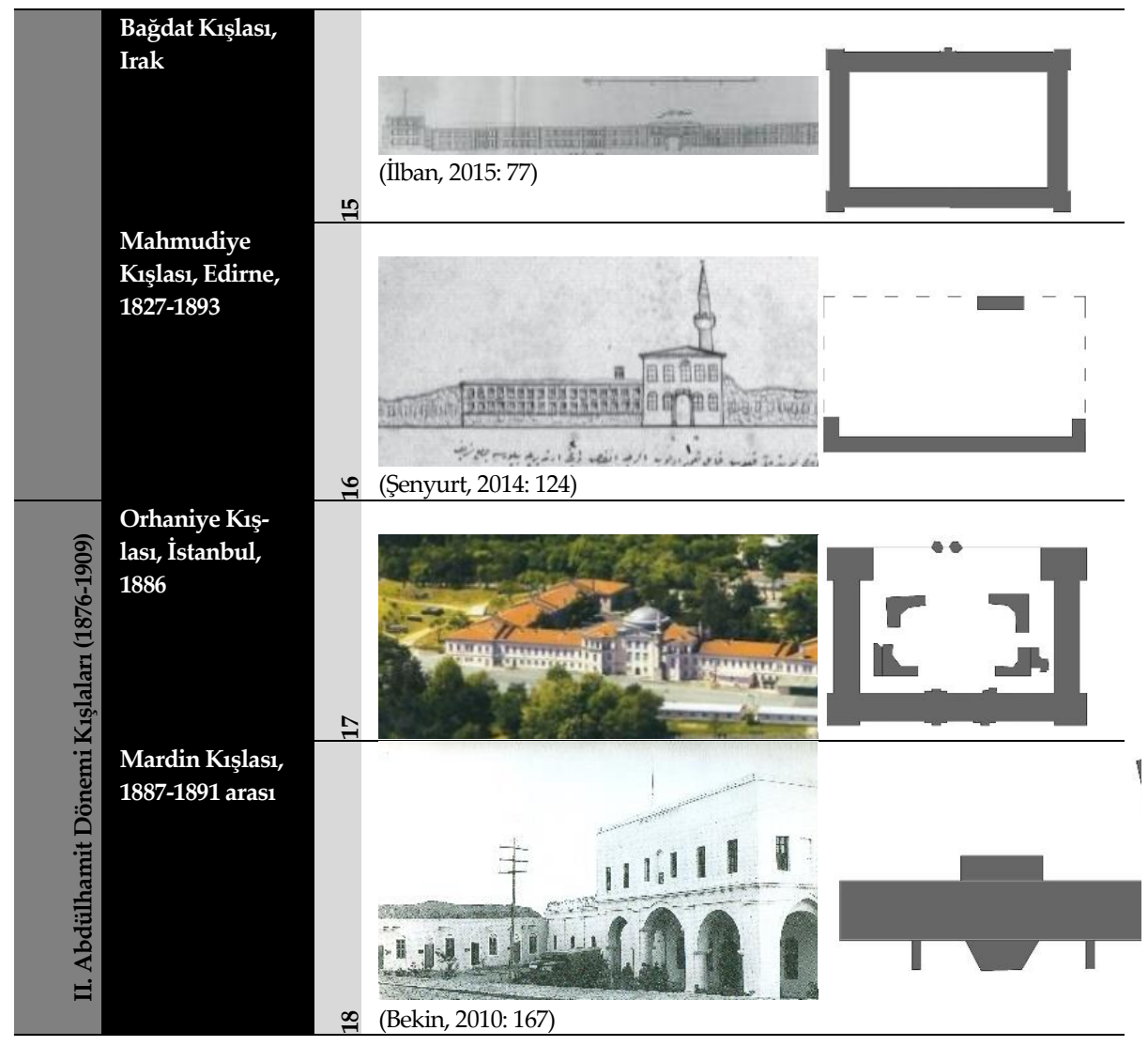

Kışla yapıları, taşrada, kışla olarak planlanıp inşa edilebildiği gibi mevcut bir konak, hastane, mutasarrıflık, vb. türdeki yapıların dönüşümü ile de elde edilebilmektedir. ${ }^{14}$ Literatürde kışla olarak geçen yapılardan, tekil yapı olarak görünenlerin bir bölümünün redif kayıt bürosu olabileceği, doğudakilerin bir bölümünün Hamidiye birliklerinin istihdamını sağlamaya dönük olarak inşa edildiği düşünülmektedir.

Aytar (2016), kışlaların çok az sayıda ahşap örnekleri bulunmasına rağmen büyük çoğunluğunun kâgir olduğunu, genellikle şehrin havadar yerlerinde ve yerleşim birimlerinin dışında, büyük bahçeler içerisinde, orta avlulu olarak yapıldığını (Mardin'de şehir merkezinde yer alır), çoğunlukla zemin ve birinci kattan meydana geldiklerinden, arazinin eğimine göre bazı kısım-

\footnotetext{
${ }^{14}$ Çataltepe (1997) Aksaray, Çankırı, Niğde, Kayseri kışlalarını bu yapılar arasında göstermektedir.
} 
larda zemin üstünde iki ve üç kata çıkıldığının da görülebileceğini, kışla içerisinde koğuşlar, cami, hamam, ahır, fırın, işlevine göre lojmanlar, su deposu, karakol gibi yapıların ya da padişahın geldiği zaman dinlenmesi için hünkar kasırlarının inşa edilebildiğini ifade eder.

XVIII. ve XIX. yüzyılda inşa edilen 59 kışladan 16'sı İstanbul'da, 14'ü Balkan yarımadasında (İstanbul hariç), 28'i Anadolu'da (İstanbul hariç), 1 tanesi Irak'ta yer alır. İstanbul'dan sonra, kışla yoğunluğunun en fazla olduğu şehir Edirne'dir (Tablo 2).

Tablo 2. XVIII. ve XIX. yüzyılda inşa edilen 59 kışla yapısı (16'sı İstanbul'da, 3'üu Edirne'de) ${ }^{15}$

\begin{tabular}{|c|c|c|}
\hline \multicolumn{3}{|c|}{ OSMANLI'DA XVIII. ve XIX. YÜZYILDAKİ KIŞLA YAPILARI } \\
\hline TARİH & KIŞLANIN ADI & YER \\
\hline 1782 & Kalyoncu Kışlası & Istanbul-Kasımpaşa \\
\hline 1792 & Humbaracılar Kışlası & İstanbul- Haliç \\
\hline 1802 ve 1805 aras1 & Aksaray Kışlası & Aksaray \\
\hline 1803 & Çankırı Kışlası & Çankırı \\
\hline 1803 & Kütahya Kışlası & Kütahya \\
\hline 1803 & Menteşe Kışlası & Muğla \\
\hline 1804 & Ankara Kışlası & Ankara \\
\hline 1804 & Seydişehir Kışlası & Konya \\
\hline (1804 sonu veya 1805) & Bolu Kışlası & Bolu \\
\hline 1805 & Daday Kışlası & Kastamonu \\
\hline 1805 & Kırşehir Kışlası & Kurşehir \\
\hline 1806'lar & Amasya Kışlası & Amasya \\
\hline 1806 & Çorum Kışlası & Çorum \\
\hline 1806 civarı & Karaman Kışlası & Karaman \\
\hline 1806 & Kayseri Kışlası & Kayseri \\
\hline 1806 civarı & Gülnar Kışlası & Mersin \\
\hline 1806 civarı & Niğde Kışlası & Niğde \\
\hline 1806 & Sivas Kışlası & Sivas \\
\hline 1806 & Taksim Topçu Kışlası & İstanbul-Taksim \\
\hline $1823-1825$ & Tophane Topçu Kışlası & İstanbul-Tophane \\
\hline 1827 (İnş. bitiş) & Davutpaşa Piyade Kışlası & İstanbul- Esenler \\
\hline 1827 (İnş. bitiş) & Rami Piyade Kışlası & İstanbul- Eyüp \\
\hline 1828 (İnş. bitiş) & Selimiye Kışlası & İstanbul-Üsküdar \\
\hline 1828 (İnş. bitiş) & Kuleli Süvari Kışlası & İstanbul-Üsküdar \\
\hline $1820^{\prime}$ ler & Kırmızı Kışla & İstanbul-Eminönü \\
\hline 1829 & İzmir Kışlası & İzmir \\
\hline 1829 & Mahmudiye Piyade Kışlası & Edirne \\
\hline
\end{tabular}

15 Tablo 2'de yer alan İstanbul kışlaları için Çiftçi ve Seçkin'in (2005: 66) "1826 Yılından Sonra İstanbul'da İnşa Edilen Askeri Yapıların Yerleri, Yapım Tarihleri, Günümüzdeki Durumları, İşlevleri, Mülkiyetleri ve Tescil Tarihleri" başlıklı tablosundan altlık olarak faydalanılmıştır. Bunlara Çataltepe'nin (1997) kitabında yer alan kışlalar ile birlikte Bashanov ve Kemaloğlu'nun kitabında (2018) yer alan askeri merkezler de eklenmiştir. 


\begin{tabular}{|c|c|c|}
\hline 1832 & $\begin{array}{l}\text { 39.Mknz. P. Tugay 2.Hd. A. Kh. } \\
\text { Srv. Bl. K.liğ } 1\end{array}$ & Hatay-İskenderun \\
\hline $1834^{\prime}$ ler & Selanik Kışlası & Yunanistan \\
\hline 1839 & Niş Kalesi Kışlası & Sirbistan \\
\hline $1836-1839$ arası & İşkodra Kalesi Kışlası & Arnavutluk \\
\hline $1836-1839$ arası & Liş Kalesi Kışlaları & Arnavutluk \\
\hline 1839 (Belgede adı geçen tarih) & Karahisar Kışlası & Afyonkarahisar \\
\hline $1839-1840$ & Demirkapı Kışlası & İstanbul- Eminönü \\
\hline 1846 & Bursa Kışlası & Bursa \\
\hline 1847 (Belgede adı geçen tarih) & Tırhala Kışlası & Yunanistan \\
\hline 1850'ler & Manastır Kışlası & Makedonya \\
\hline 1861-1862 & Galatasaray Piyade Kışlası & Beyoğlu-İstanbul \\
\hline 1862 & Gümüşsuyu Piyade Kışlası & Beyoğlu-İstanbul \\
\hline 1862 & Mecidiye Kışlası (Taşkışla) & İstanbul \\
\hline 1863 & Samsun Kışlası & Samsun \\
\hline 1863 & Bağdat Kışlası & Irak-Kerkük \\
\hline 1868 & Sivrihisar Kışlası & Eskişehir \\
\hline 1868 & Yenipazar Kışlası & Sirbistan \\
\hline 1870 & Çimenlik Kışlası & Çanakkale \\
\hline 1870 & Silistre Kışlası & Bulgaristan \\
\hline 1870 & Yanya Kışlası & Yunanistan \\
\hline 1872 & Harbiye Kışlası & Edirne \\
\hline 1872 & Diyarbakır Kışlası & Diyarbakır \\
\hline 1873 & Debre Kışlası & Makedonya \\
\hline 1878 & Süvari Kışlası (Tunca Kışlası) & Edirne \\
\hline 1880'ler & Süvari Kışlası & İstanbul-Eminönü \\
\hline 1880'ler & Ertuğrul Piyade Kışlası & İstanbul-Beşiktaş \\
\hline 1883 & Trabzon Kışlası & Trabzon \\
\hline 1884-1885 & Orhaniye Süvari Kışlası & İstanbul-Beşiktaş \\
\hline 1887 ve1891 aras1 & Mardin Kışlası & Mardin \\
\hline 19.yy & İzmit Kışlası & İzmit \\
\hline 19.yy & Antalya Kışlası & Antalya \\
\hline 19.yy & Aydın Kışlası & Aydin \\
\hline
\end{tabular}

Yapıların bir bölümü; inşasına ilişkin karar, bir bölümü; üzerindeki kitabe, inşa edildiği dönemdeki padişahın taht süresi ya da valinin idarecilik süresi, vd. şekillerde literatüre girdiği için veya inşa kararı ve inşaatın bitişi arasında on yılları bulan zaman diliminin olması, bu inşaları kronolojik açıdan kesin olarak konumlandırmayı zorlaştırmaktadır. Bu, ayrı bir çalışmanın konusu olabilir. Ancak 1782'de ilk kışlanın inşa edilmesinden sonra 1807'ye kadar, Anadolu'da kışla inşa faaliyetlerinin yoğunlaştığ bir dönemdir. 1806-1822 tarihleri arasındaki yaklaşık 20 yıl, kayıtlı herhangi bir kışlaya ulaşılamamıştır. Kışla inşa yoğunluğunun, 1892 sonrasında ise azalmaya başladığı görülür.

Kışla yoğunluğu doğuya doğru azalır (Şekil 2). Doğuda inşa edilen Trabzon, Diyarbakır ve Bağdat kışlaları da Mardin Kışlası gibi, Osmanlı'nın son 
dönem kışlalarıdır. Mardin Kışlası, bu yapılar arasında küçük ölçekli bir yapıdır. Nitekim (XIX. yüzyıl sonu ve XX. yüzyıl başındaki askeri mimari kitaplarındaki) teknik şartnamede alay/lar üzerinden ölçeklendirilen kışla yapılarına göre, iki bölük askerin istihdamına yönelik olarak inşa edilen Mardin Kışlası'nın, Anadolu kışlaları arasında da oldukça küçük ölçekli bir yapı olduğu ifade edilebilir. ${ }^{16}$ Bununla birlikte Anadolu kışlaları ile daha detaylı bir karşılaştırma yapmak, bu yapılar ile ilgili literatürün kısıtlılığı nedeniyle zor görünüyor.

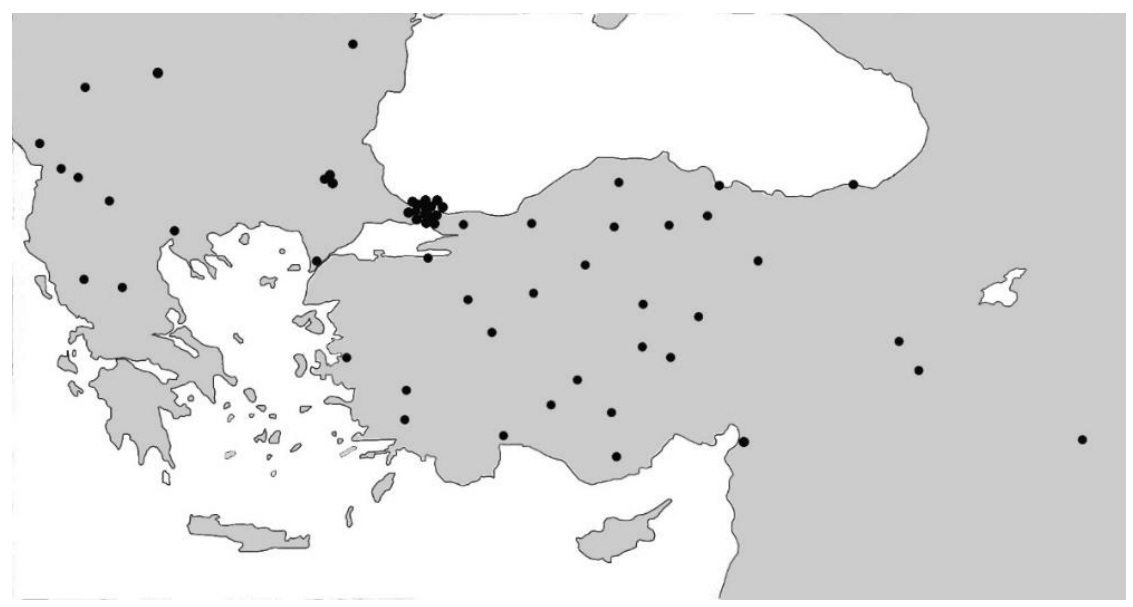

Şekil 2. Osmanlı' da XVIII ve XIX. yüzyılda inşa edilen kışlaların dağılımı

Kesin ve kanıtlanmış bir bilgi olmasa da, Mardin Kışlası'nın yapımında Ermeni taş ustası Sarkis Elyas Lole'nin emeğinin olduğu, hatta doğrudan onun tarafından yapıldığı sözlü olarak rivayet edilmektedir. Kâgir bir yapıdır. Şehirdeki diğer uygulamalarda olduğu gibi, inşasında kullanılan malzeme, bölgede çıarılan taştır (Resim 3-6). Yapım teknikleri, iç tonozları, duvar örgüleri, 19. Yüzyıl süsleme programları vb. açılarından da şehir genelindeki sivil ve dini mimari uygulamalarına benzerlikler taşır (Resim 7-12). Baydaş (2007, s.143) Kışla'ya ait kitabede tarihi ifade etmesi muhtemel olan izlerin belirsiz ve silik olduğunu, kaynaklarda II. Abdülhamit döneminde Hacı Hasan Paşa'nın Diyarbakır valiliği yaptığı sırada inşaatına başlanmış olduğunu, Hacı Hasan Paşa' nın 1887-1891 tarihleri arasında valilik yaptığından inşaatın bu tarihlere ait olabileceğini ifade etmektedir.

${ }^{16}$ Mardin Kışlası'nın iki bölük askerin istihdamı için inşa edildiği bilgisi için bkz. İrade-i Meclis-i Vâlâ, 1891. 

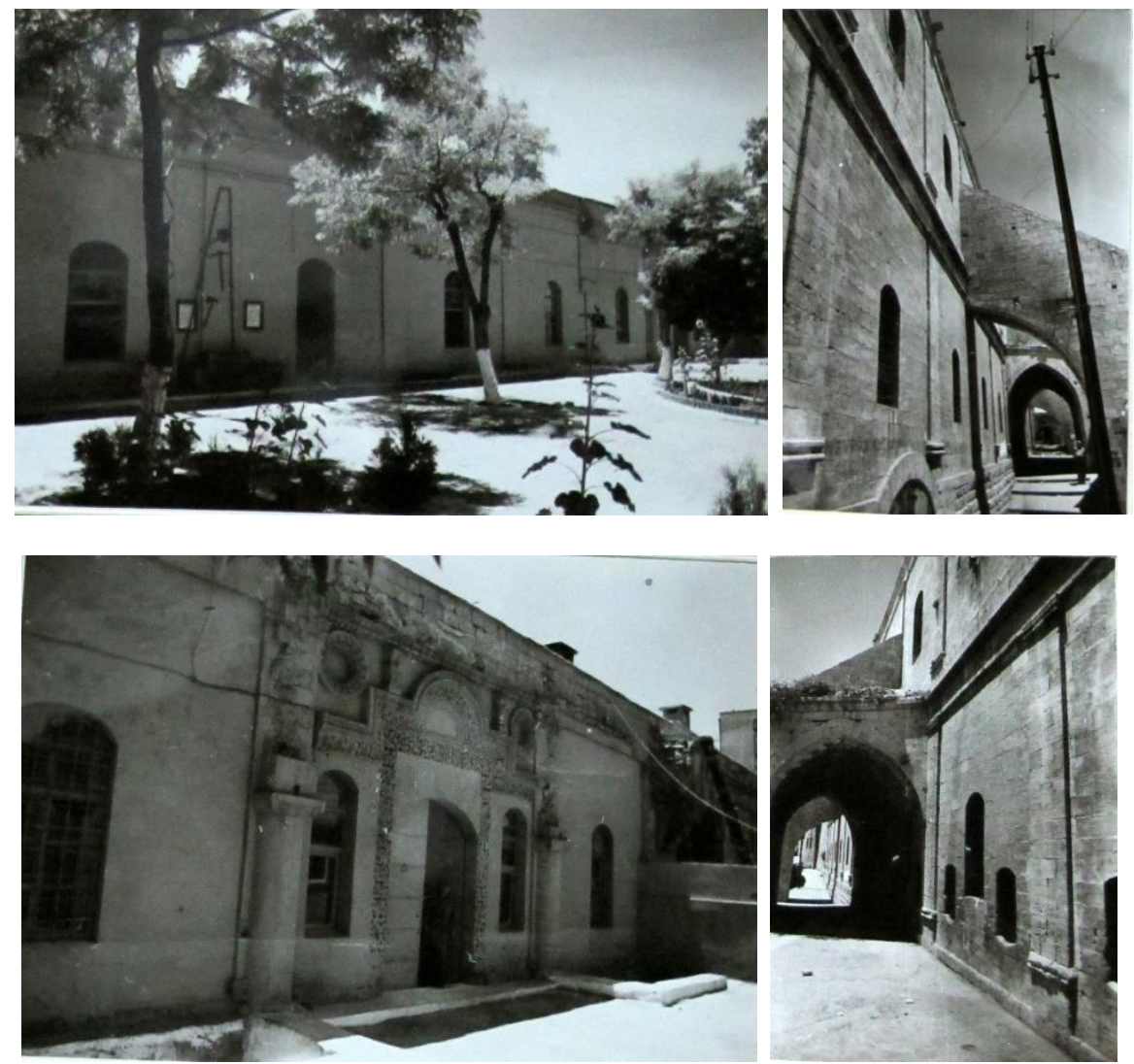

Resim 3, 4, 5, 6. 1970'li yıllarda Mardin Kışlası (Fotoğraflar: Diyarbakır Kültür Varlıklarını Koruma Bölge Kurulu Arşivi)
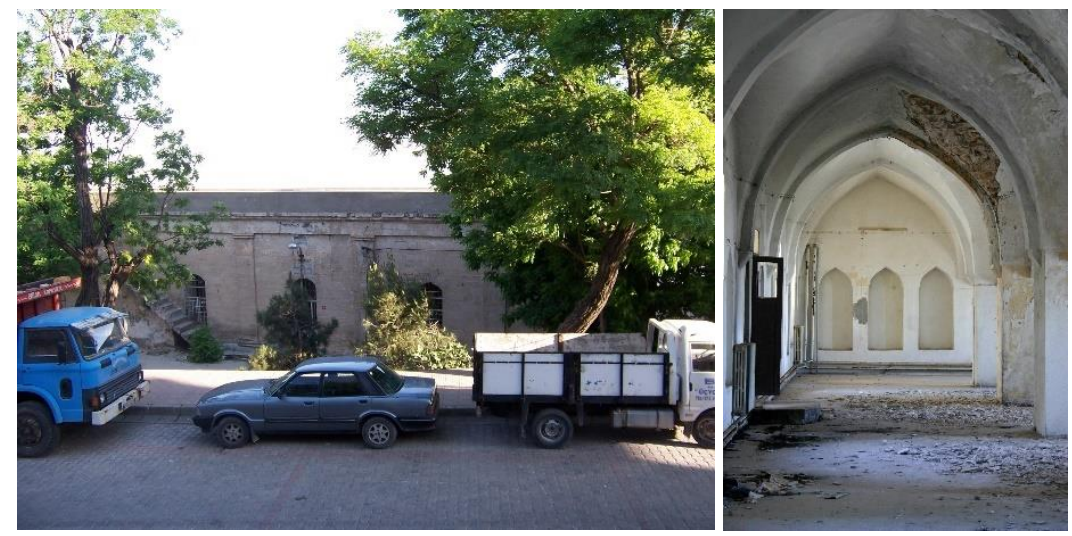

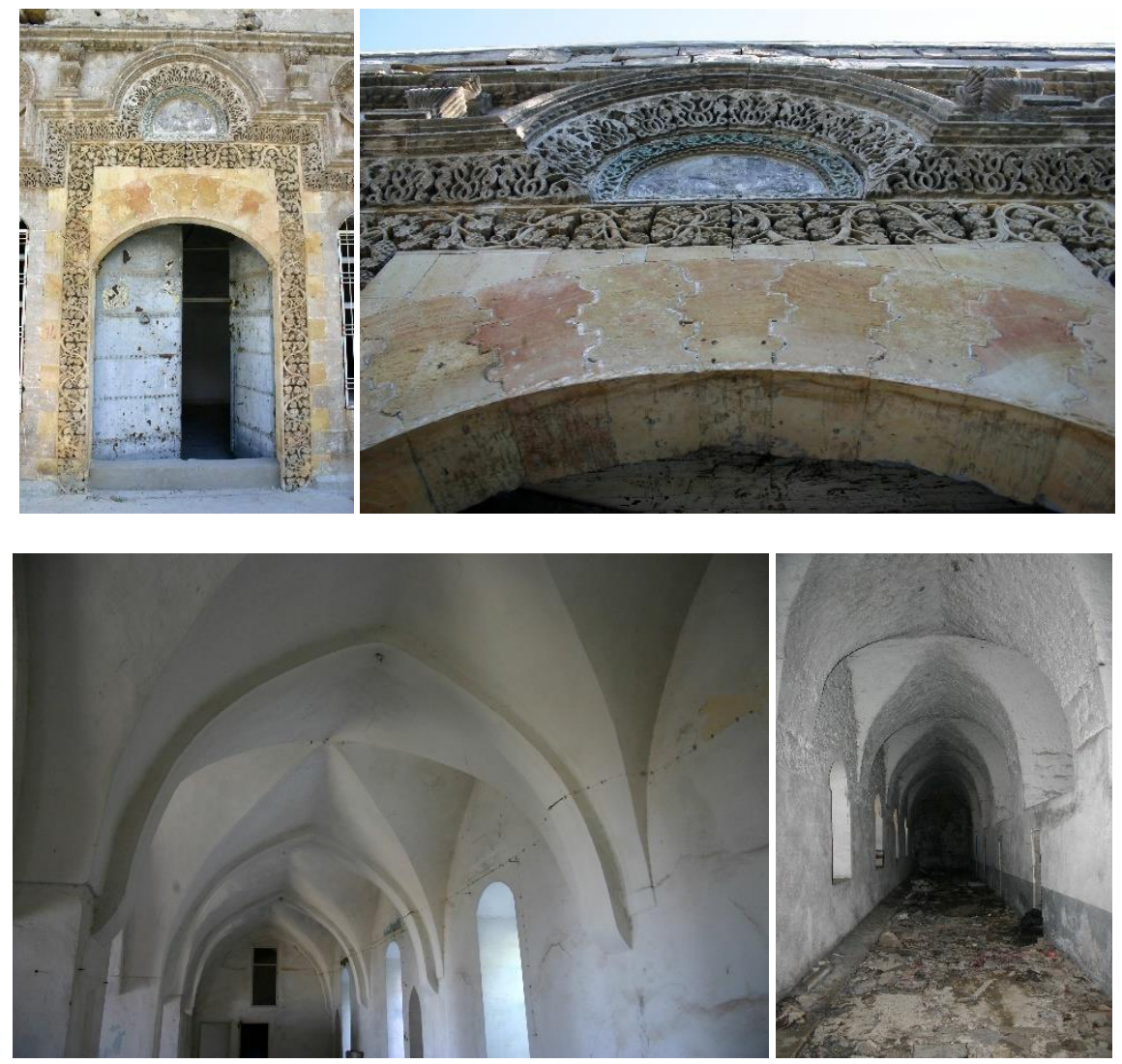

Resim 7, 8, 9, 10, 11, 12. Mardin Kışlası'nın 2005 yılında, restorasyondan önceki hali (Fotoğraf: Abdülgani Tarkan)

Kışla, L biçiminde biraraya gelen iki ayrı bloktan oluşur. L biçimi, bu dönemdeki kışla şartnamesinde tanımlı üç tip arasında yer almamaktadır. Ancak şartnamede de belirtilen topoğrafik koşullardan ötürü zemine kademeli olarak yerleşir. Bu, ayn zamanda, şehirdeki yerleşimin de genel karakteridir. Yapı, topoğrafyaya bağlı olarak, kuzey cephesinde tek, güney cephesinde ise iki katlı gözükecek şekilde inşa edilmiştir. Bu şekliyle şehirdeki diğer yapıların kesit yerleşimleri ile benzerlik gösterir. Üst zemin kat, kuzey yönünde avluya açlır. Yapının ana girişi bu avludadır. Avluda, girişin sağ ve solunda bulunan iki merdiven aracılığıyla alt zemin kata ulaşılabilir. Güney yönündeki ara sokaktan alt zemin kata bir giriş daha verilmiştir. 
Yapı, genel itibariyle, şehir mimarisindeki yapılarda (kamusal ve özel yapılar) oda-eyvan-avlu/teras olarak tekrar eden, zaman zaman revak dizilimleriyle sürdürülen kapalı-yarı açı-açık mekan organizasyonundan belirgin bir biçimde sapma eğilimindedir. Yapının kuzey cephesinde ilk yapıldığında bulunan ve girişi örten kâgir revağın da yıkılmasıyla, bu ilişki kapalı ve açık mekan (avlu) olarak kalır. Yaklaşık 60 metre boyunca kesintisiz (eyvansız ve terassız) devam eden bir kapalı mekana sahiptir (Tablo 3). Şehirde, bu tür kesintisiz bir kapalı mekana sahip en büyük tarihi örnek Ulucami' dir.

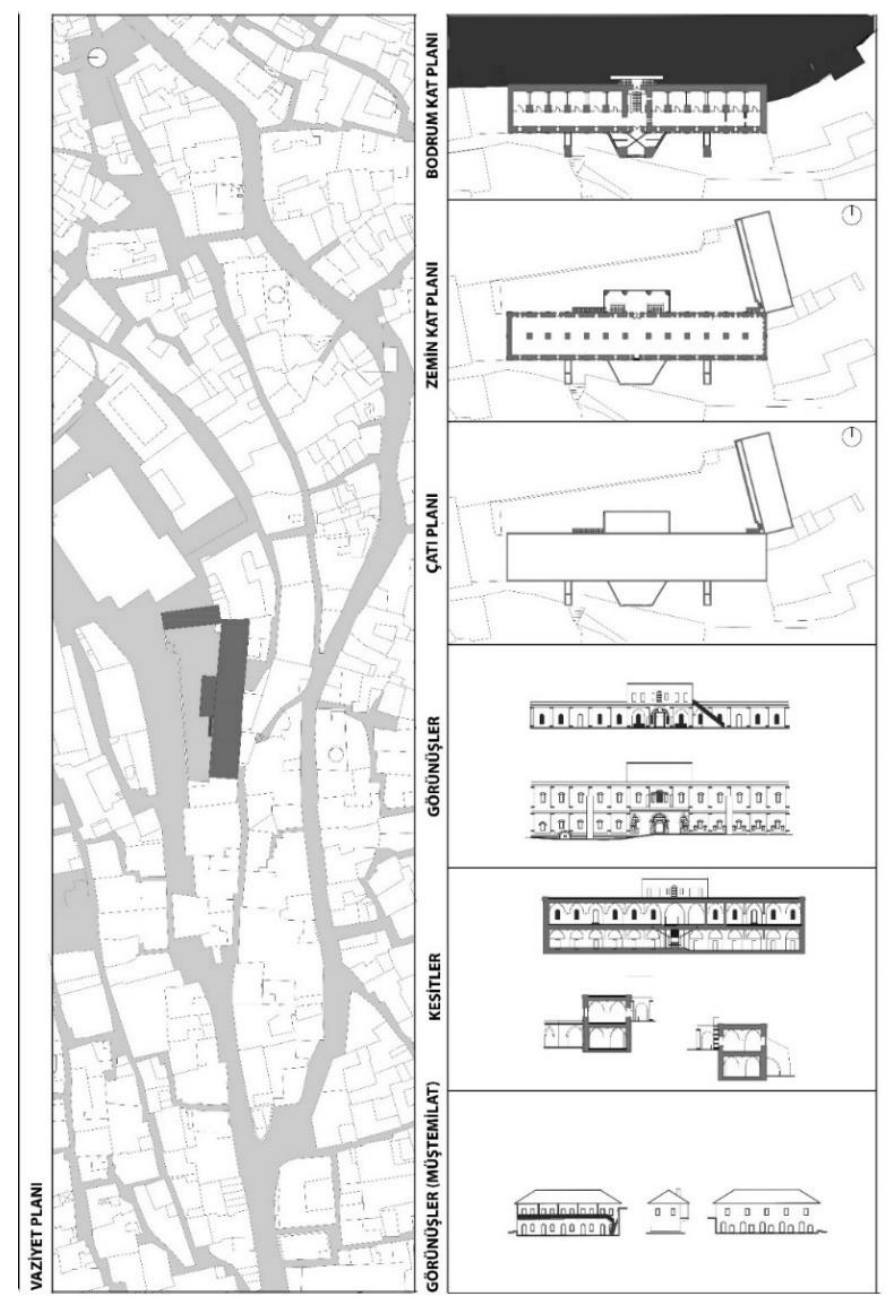

Tablo 3. Mardin Kışlası'nın vaziyet planı ve restitüsyonu (Mehmet Ata İletmiş ve Fethullah Duyan tarafından çizilen restitüsyon ve rölöve projesinden uyarlanmıştır) 
Yapının kuzeyindeki avlu, Hükümet Meydanı'na bakar. Hükümet Meydanı'nın çevresinde, kışla ile yakın dönemlerde inşa edilen Hükümet Konağı, Belediye Binası, Vali Konağı gibi yapılar yer alır (Resim 13). Kışla ve avlunun meydandan alçak bir duvar ile ayrılması, meydan ile görsel ilişkinin sürdürülmesini sağlar. $\mathrm{Bu}$, yapıların yüksek duvarlar tarafından çevrelenerek yol ve sokaktan kesin sınırlarla ayrıldığı geleneksel Mardin şehri için yaygın bir uygulama sayılmaz.

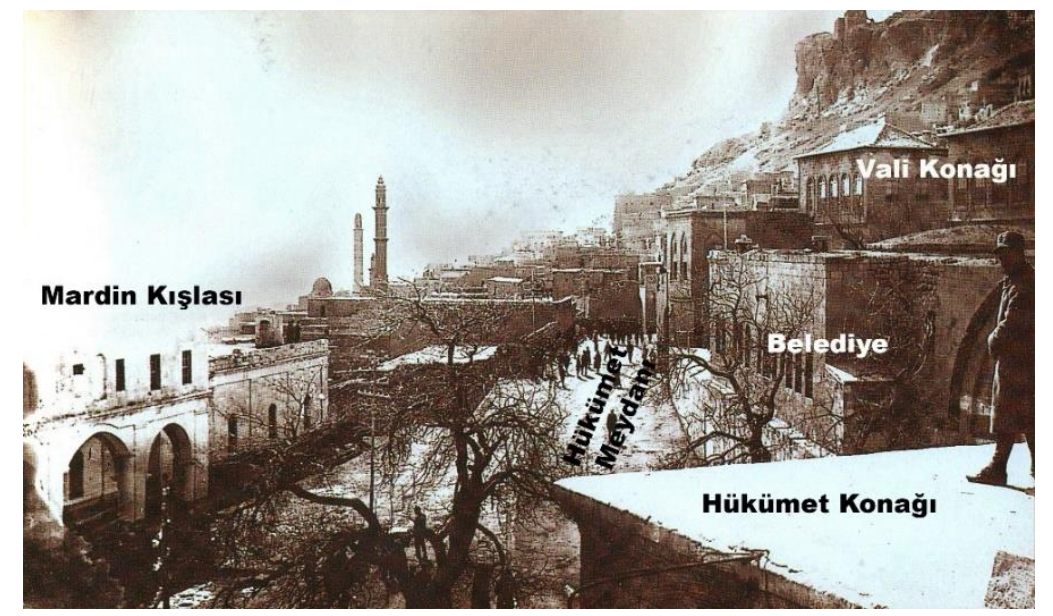

Resim 13. Mardin Hükümet Meydanı ve çevresindeki yapılar (Bekin, 2010, s.145)

Taş ayaklar üzerinde yükselen çapraz tonozlar, üst zemin katta kesintisiz bir iç mekan ortaya koyar. Tonozlar, dışarıdan algılanmaz, yapı düz çatılıdır. Avludaki tek kollu bir merdivenle çatıya çıkılır. Alt zemin kat, bir giriş holü ve bu holün sağ ve solunda yer alan iki ayrı mekandan oluşur. Burası, yani alt zemin kat, bu dönemdeki kışla inşa şartnamesinde belirtildiği gibi, yemliklerinin de bulunduğu kışlanın ahır bölümüdür (Baydaş, 2007, s.146). Yap1nın güney cephesinde sokağa doğru uzanan iki adet payanda, güney duvarını destekler. Güney girişinin üzeri, dışarıdan, ayaklar üzerine oturtulmuş çapraz tonozlar ile örtülür.

Mardin Kışlası'nın inşasında, malzeme, yapım sistemi ve strüktür, topoğrafya ile ilişkisi açısından yerel imkanların da değerlendirilmiş olduğu ifade edilebilir. Mekân örgütlenmesi ve hiyerarşisi açısından ise şehirdeki diğer uygulamalardan farklılaşır. Bu, yapının, modern-merkeziyetçiliğin tesis edilmesine aracılık eden yeni tür yapılardan biri olarak, yapının yerleşik kalıplar ya da artifaktlar ile de ilişkiyi, kısmen sürdürmekte olduğu biçiminde yorumlanabilir. 


\section{Kışladan Müzeye: Mardin Kışlası'nın XXI. Yüzyıldaki Dönüşümü}

Çalışmanın bu bölümünde, askeri ve mekansal yönlerden ortaya koyduğu yeni önermelerle bir dönem şehirdeki modern mekan deneyiminin öncülerinden biri olan kışlanın, yüz yıl sonra müzeye dönüşümü ve yapıda gerçekleştirilen müdahaleler ele alınarak, bu şekilde şehirde ortaya çıkan yeni modernlik yönelimleri ${ }^{17}$ üzerinde durulacaktır.

Mardin Kışlası bir süvari kışlası olarak inşa edilmiş, günümüze kadar; sırasıyla, jandarma komutanlığı, askerlik şubesi, jandarma karakolu olarak kullanılmıştır, (Baydaş, 2007, s.143-144). En son, 1991-2003 tarihleri arasında üst zemin katı vergi dairesi olarak hizmet vermiş (bu esnada alt zemin kat hayvan barınağı olarak kullanılmaktadır), boşaltıldıktan sonra 2009 tarihinde restorasyonu tamamlanıp müze olarak açılışı yapılmıştır (Mardin'i Dinlerken, 2012, s.4, 58, 63). XIX. yüzyılda ikinci yapı olarak inşa edilen ve ana kışla binasına "L" oluşturacak biçimde eklemlenen küçük diktörtgen planlı yapı ise başlangıça tek katlıdır. Sonradan yapıya ikinci kat eklenmiş, restorasyon sırasında ise (2008-2009) tamamen yıkılarak yeni bir ek bina inşa edilmiştir (Resim 14-16).
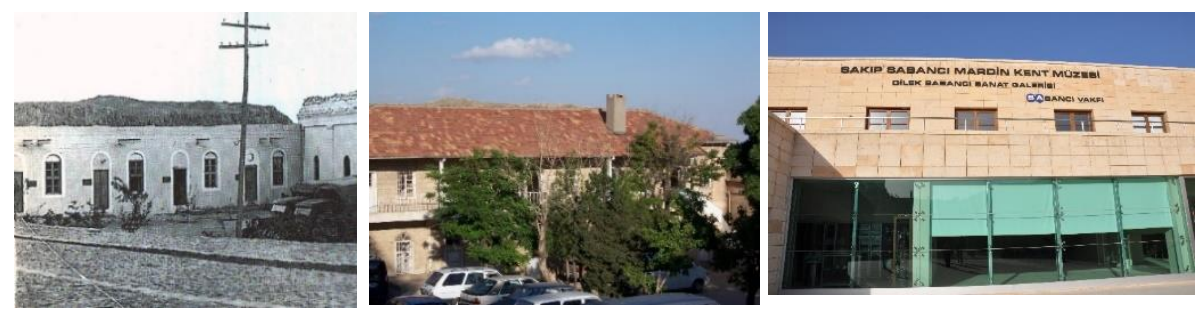

Resim 14, 15, 16. Kışla ikinci binanın XIX. yüzyıl sonu (Bekin, 2010, s.167), 2005 yılı (Fotoğraf: Abdülgani Tarkan) ve 2010 yılı fotoğrafları (Fotoğraf: Halil İbrahim Düzenli)

\footnotetext{
${ }^{17}$ Kentleşme sürecinde Mardin'in imarının büyük ölçekte gerçekleştirildiği iki dönem vardır. Bunlardan birincisi, Artuklu Beyliği'nin hüküm sürdügü XII. ve XV. yüzyıllar arasında başkent ilan edilmesi ile başlar. Tuncer, bu dönemde Mardin' de 10 cami, 2 mescit, 8 medrese, 3 hamam, 1 maristan, 1 çeşme, 1 kervansaray, 1 köprü ve 3 saray inşa edildiğinden bahsetmektedir (Tuncer, 2007). İnşa edilen yapı türüne istinaden bu dönemde Mardin'in kentleşme faaliyetleri ile birlikte bir İslam coğrafyası imajının pekiştirildiği ifade edilebilir. İkinci olarak; Mardin Kışlası' nın bir Kent Müzesi'ne dönüşümü ile başlayan süreç, müzenin çevresindeki yapıların dönüşümü ile artarak devam eden ve sonunda bir müze kent deneyimini ortaya çıkaran büyük çaplı bir "restorasyon" hareketinden bahsetmeye imkan tanır.
} 
Kışla, şehirdeki ilk müze değildir. Mardin'de, etnografik eserlerin sergilendiği ilk müze, bundan yaklaşı 60 yll önce, 1947'de, devlet eliyle kurulmuştur. Mardin'in ilk müzesinin kuruluşu ile başkentte Cumhuriyet'in ilk müzesi olan Etnografya Müzesi'nin kuruluşu arasında ise yaklaşık 25 yıl bulunmaktadır. Mardin'deki özel bir teşebbüs olan yeni müze, 1980'de İstanbul'da Türkiye'nin ilk özel müzesinin açlışından yaklaşık 30 yıl sonra, 2009'da kurulmuştur.

$\mathrm{Bu}$ bağlamda, müzeciliğin modernleşme geleneği ile kurduğu ilişki ve müzeciliğin şehre taşınımının, kışlanın inşası ile kentsel alanda da deneyimlenmeye başlanılan modern/merkeziyetçiliğin bir uzantısı olarak ele alınabileceğinden, yine kışlanın inşasında olduğu gibi şehirdeki bu deneyimin merkezdeki ilk uygulamaya göre gecikmeli olarak gerçekleştiğinden bahsedilebilir. Bu noktada, şehirde ilk müzenin kuruluşu, modernleşme deneyimi aç1sından bir yenilik ortaya koymamaktadır. Kışlanın müzeye dönüşümü ise, uygulamanın biçim ve içeriği, finansmanı açsından ele alındığında, yeni bir modernlik çizgisinden bahsetmeye olanak tanır.

Kışlanın müze olarak renovasyonu sürecinde yapıda; gerek yeni işlevsel ihtiyaçları karşılamaya, gerekse yapıda zamanın etkisiyle ortaya çıkan tahribatları gidermeye dönük bir dizi müdahale gerçekleştirilmiştir. Üst kattaki iç duvarların ve alt katlardaki ahır bölümünde yer alan bölücü duvarların ortadan kaldırılması ve yapının güney doğusunda, cepheyi kapatan dolgunun temizlenmesi, bunlar arasındadır (Tablo 4) (Resim 17-21).
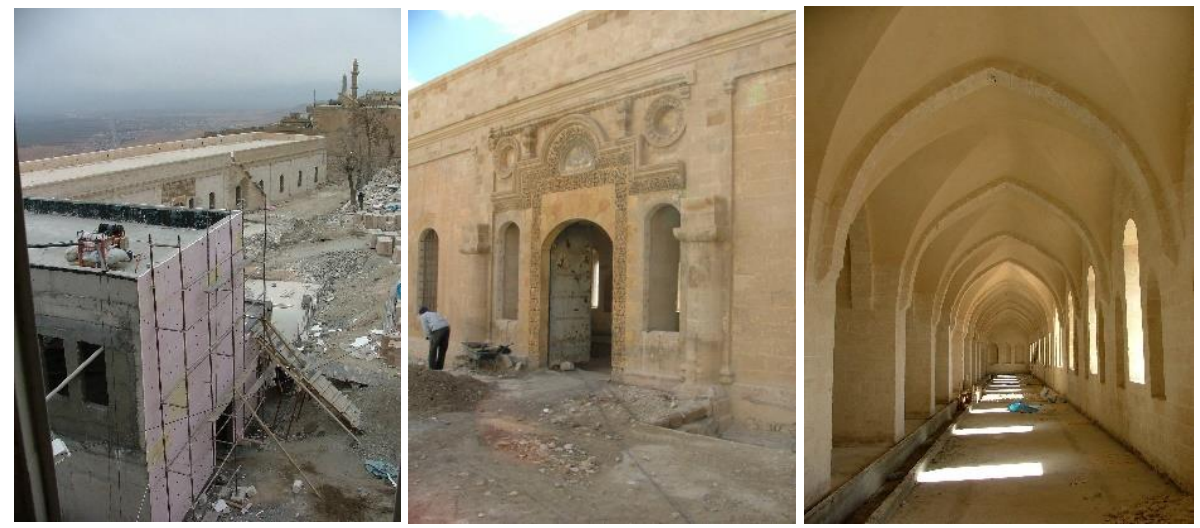

Resim 17, 18, 19. Sakıp Sabancı Mardin Kent Müzesi'nin restorasyonu sırasında, Kasım 2008-Ocak 2009 arasında çekilmiş fotoğrafları (Fotoğraf: Halil İbrahim Düzenli) 


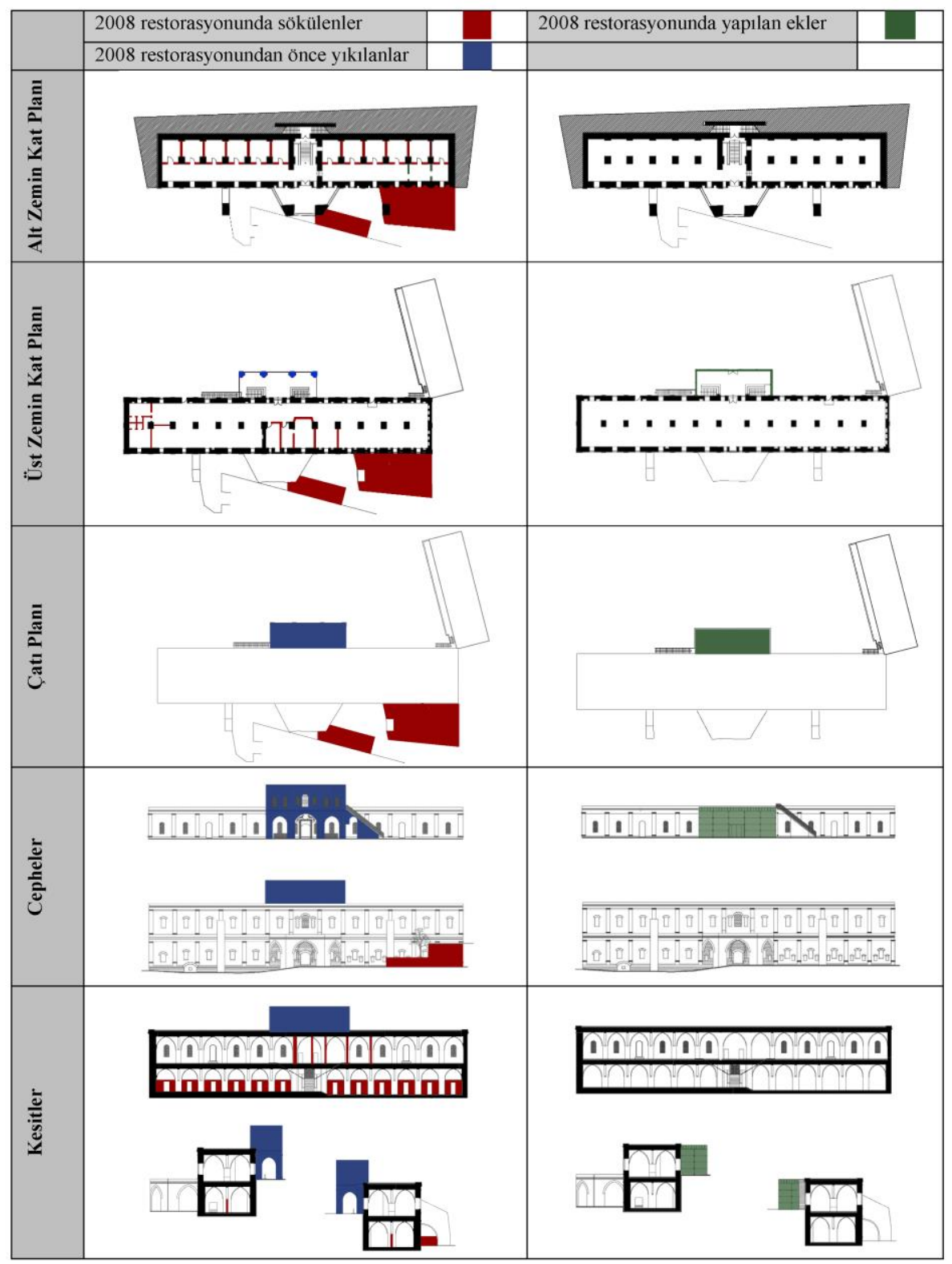

Tablo 4. Mardin Kışlası'nın 2008 restorasyonu öncesi ve sonrası durumu (Mehmet Ata İletmiş ve Fethullah Duyan tarafından çizilen restitüsyon ve rölöve projesi üzerinden uyarlanmıştır) 

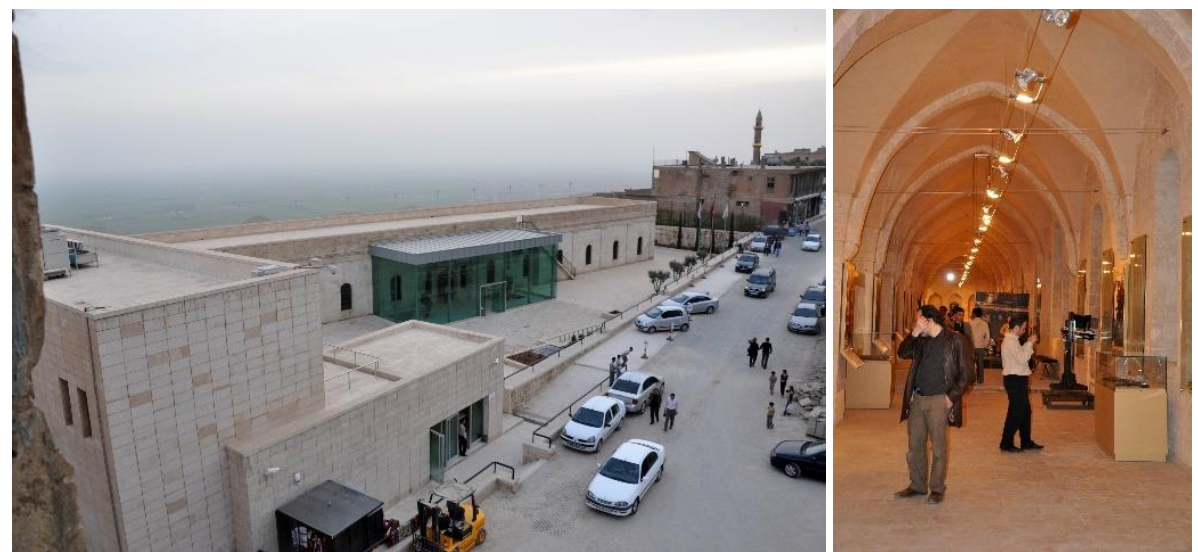

Resim 20, 21. Restorasyon sonrası (2010) Sakıp Sabancı Mardin Kent Müzesi (Fotoğraf: Halil İbrahim Düzenli)

Yapının orijinalinde mevcut olmayan en kayda değer müdahale, yapıda bol tezyinatıyla dikkati çeken portalin önüne cephe yüksekliği boyunca bir camla kapatılmış giriş mekanının eklenmesidir. Bu mekan, yapı ilk inşa edildiğinde burada bulunan ve sonralarda yıkılan kâgir revağın yerine inşa edilmiştir. Bu şekilde, yapıda, açık- yarı açık-kapalı mekan biçiminde ortaya çıkan mekansal hiyerarşinin açık-kapalı mekan biçiminde farklılaştığı görülür. Söz konusu mekan, malzeme ve teknik açısından da eski yapıda olduğundan farklı bir deneyim ortaya koyar. Örümcek (spider) akrobat giydirme cam cephe çelik kolonlara taşıtılır. Mekan, asma tavanla örtülmüş ve spot 1şıklarıyla aydınlatılmıştır (Resim 22, 23).

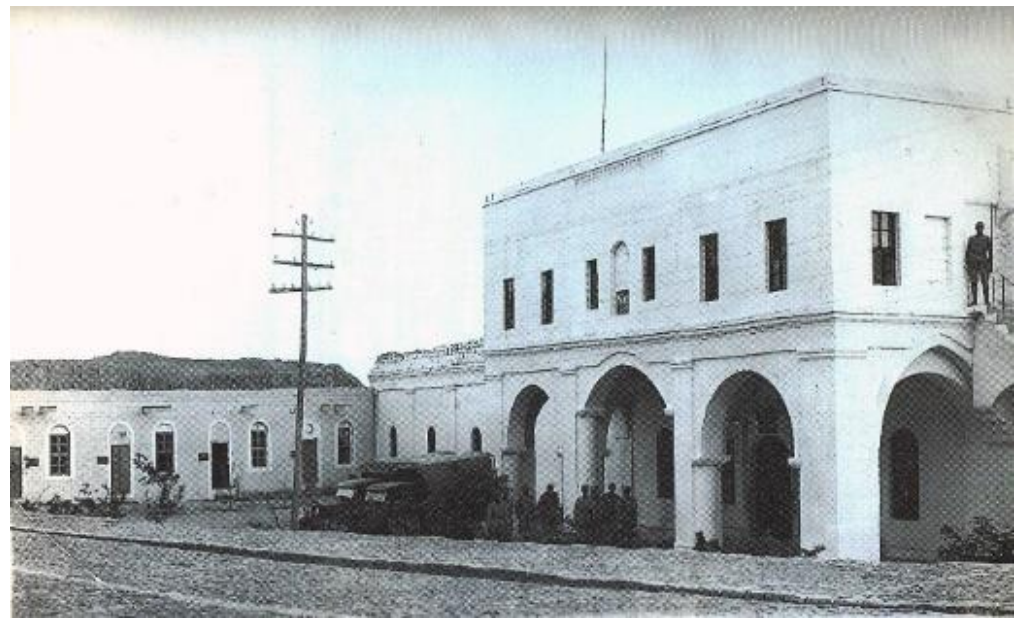

Resim 22. Binanın XIX. yüzyıl kışlası (Bekin, 2010: 167) dönemindeki giriş mekanı 


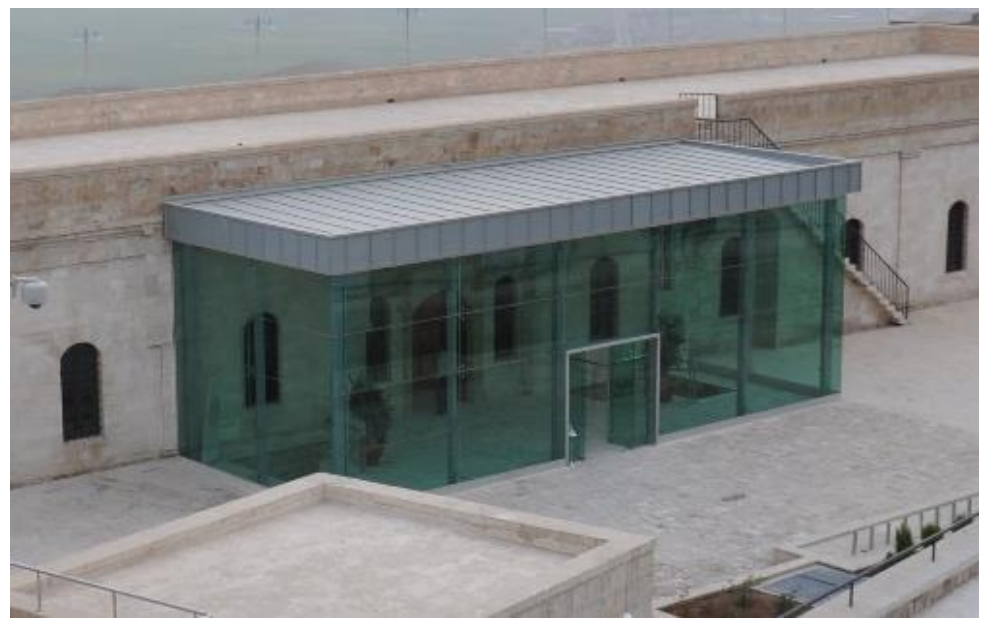

Resim 23. Binanın XXI. yüzyıl müzesi dönemindeki giriş mekanı (Fotoğraf: Halil İbrahim Düzenli)

Üst zemin katta bir adet kalıcı sergi bulunur ve adı Sakıp Sabancı Mardin Kent Müzesi'dir. Alt zemin kat iki adet geçici sergi salonu olarak düzenlenmiştir. Adı ise Dilek Sabancı Sanat Galerisi'dir. Kalıcı sergide, Mardin ve çevresindeki çeşitli el sanatları, şehirdeki dinsel çeşitliliği örneklendiren mezar taşları ve gündelik yaşantı nesneleri, gündelik hayatın geçtiği ev ve atölye mekanlarındaki faaliyetlerin, balmumu insan yerleştirmeleriyle canlandırıldığı çeşitli enstalasyonlar, ekranlardan sürekli olarak gösterimi yapılan Mardin kültürü ile ilgili belgeseller, fotoğraf ve tanıtıc posterler yer almaktadır. 1 Ekim 2009'da açılışı yapılan Dilek Sabancı Sanat Galerisi'nde ise Mardin'e getirilen önemli geçici sergiler düzenlenmiştir. Bugüne kadar gerçekleşen geçici sergiler şunlardır: "Sabancı Üniversitesi Sakıp Sabancı Müzesi Koleksiyonu'ndan Seçmelerle - Doğa, İnsan ve Deniz" (Açılış: 1 Ekim 2009); “Abidin Dino Mardin'de - Seçme Yapitlar 1930 - 1990" (Açılış: 25 Ekim 2010); "Seyreyle... Ara Güler Mardin'de" (Açılış: 3 Kasım 2011); “Mardin'de Bir Oryantalist: Marius Bauer" (15 Mayıs 2013); “Batı'nın Gözüyle Doğu Fotoğrafları" (5 Ekim 2013); "Ai Weiwei Mardin'de" (4 Mayıs 2018); "Fotoğrafın Türlü Halleri-Murat Germen: Kesit Retrospektif" (10 Eylül 2018); “Belgeden Kurguya, Atölyeden Müzeye - Mardin'den Fotoğraflar" (30 Nisan 2019) (Resim 2428). ${ }^{18}$

${ }^{18}$ Sergilerle ilgili ayrıntılı bilgiler için bkz. URL-1. 

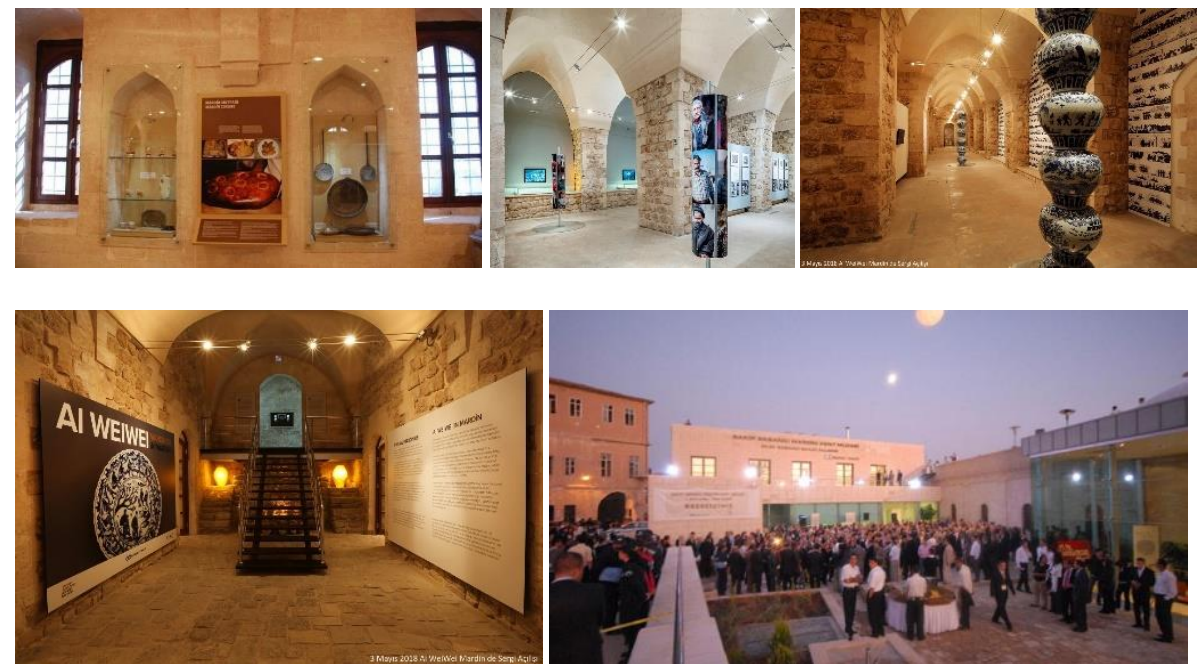

Resim 24, 25, 26, 27, 28. Müze ve Sanat Galerisi'ndeki sergilerden örnekler (URL-1)

Kışlanın restorasyonu ve dönüşümü, uzun süren bir bağlantı trafiğinin ardından Sabancı ailesi tarafından gerçekleştirilmiştir. Müze, yukarıda bahsedilen sergi içeriği, sergileme yöntemi ve sergi mekanının ele alınışı açısından olduğu kadar, kurucu aktörleriyle de değerlendirilebilir. Bu bağlamda, şehirde 1947'de devlet eliyle kurulmuş olan ve etnografik eserlerin sergilendiği şehrin ilk müzesinden farklıdır. Kışlanın kurucu unsuru olan devlet merkezli otorite, kışlanın müzeye dönüştürülmesinde yerini, Cumhuriyet burjuvazisine bırakmıştır. Bu, kültürel, mimari, ekonomik, sanayi, vd. her türlü modern uygulama anlatısındaki devlet merkezlilik başka bir duruma evrilmektedir. Devletin ekonomik üretimdeki rolünü yeni ortaya çıkan burjuvazi ile paylaşmaya başlaması, buna bağlı modernlik görünümlerinin de çeşitlendiği bir sürecin ortaya çıkmasının ifadesi olarak görülebilir.

Müze, böylelikle, fikrin ortaya çıkışından restorasyon sürecine, sergi temaları, eserler ve yapı içinde oluşturulan özel sergi koşullarına (1şıklandırma, dekor, fanus, vd.) kadar, bu aktörler tarafindan ortaya koyulan bir dizi tercihten bahsetmeye imkan tanır. Bu tercihlerle, somut ve varyantlar biçiminde çoğaltılabilecek (kavramlar, bağlamlar gibi) soyut şehir kültürü, sınırlı sayıdaki seçili örnek ve temalar üzerinden, tüm anlamsal eksiltmeleriyle beraber "evrensel kültür" imajını pekiştirecek bir biçimde yeniden inşa edilmektedir. Mezar taşları, posterler, videolar aracılığıyla yapılan dinsel çeşitlilik vurgusu, yapının güneyindeki sokağa, yapının banisi olduğu rivayet edilen (literatürde böyle bir kayda ulaşılamamıştır) Lole'nin isminin verilmesiyle de arttı- 
rllarak sürdürülür. ${ }^{19} \mathrm{Bu}$ şekilde metalaştırılan kültür, şehirli ya da turist, herkes için bir kullanım ve tüketim değerine sahip olur (Düzenli, 2012, s.85). Kültürün metalaştırılması, yukarıda bahsedilen seçmeci üslup aracılığıyla olduğu gibi tarihselci anlayışla da olabilmektedir. Sergilenen diğer nesnelerle beraber, çeşitli medeniyetlere ev sahipliği yapan şehrin "kadim" tarihini aktaran posterler ve yeni tür malzeme ve teknikler kullanılarak inşa edilmesinin etkisiyle arkasındaki eski yapının tarihsel konumunu güçlendiren cam giriş mekanı da böyle bir düşüncesinin altını çizer.

\section{Sonuç}

Mardin Kışlası'nın inşası ve yaklaşık yüzyıl üzerine müzeye dönüşümü ile, şehir, birbirinden farklı iki modernlik deneyimine sahne olur. Kışlanın inşası, XIX. yüzyıl sonlarında, özelde askeri alandaki, genel anlamda ise tüm bir devlet yapısının dönüşümünü ifade eden, geçmişte olduğundan farklı bir modern bir yönetim ve merkeziyetçiliğin aracısıdır. Müze ise, kışlanın tarihselliğiyle de pekiştirilen ve Mardin kültürünün sermaye üretiminin bir parçası olarak metalaştırılarak küresel dolaşıma girmeye başladığı bir başka modernlik sürecinin şehirdeki ilk temsilcisidir. XIX. yüzyıl sonu ve XXI. yüzyılın başlarında kışla yapısı üzerinden gerçekleştirilen bu iki uygulama, Anadolu'nun bu bölgesinde temas edilen modernlik anlayışlarından ve mekanın/binanın bu anlayışlardaki çeşitli konumlarından kesitler sunmaktadır.

Mardin Kışlası' nın inşası, İstanbul'da 1872' de ilk kışlanın inşa edilmesinden yaklaşık 100 yıl sonra gerçekleştirilmiştir. Esasen, bu, oldukça geç bir tarih sayılabilir. İmparatorluğun içinde bulunduğu mali durum, iletişim ve erişim imkanlarının sınırlılığı, bu gecikmenin nedenleri arasındadır. Diğer taraftan merkezi otoritenin etkisinin zayıflamaya başlaması, tüm yenileşme hareketlerine ek olarak, şehirde bir kışlanın inşasını gerekli kılmış gibi görünüyor. Bu haliyle kışla, şehirdeki modern-merkeziyetçiliğin de kuvvetli göstergeleri arasındadır.

Kışlanın dönüşümü için ihtiyaç duyulan desteğin sağlanmasında ise, tekil yapının yüzyıllık tarihselliğinin yanında, şehrin paleolitik çağlara dayandırılan geçmişi ve Anadolu'da tarihselliğini büyük oranda korumuş nadir yerleşkelerden biri oluşu etkili olmuş gibi görünüyor. Bu noktada, müzenin, küresel sermaye için, çevresindeki doku ile beraber mekansal ve kültürel bir rezerv ortaya koymaktadır. Şehir dokusu içindeki nispeten yeni inşalardan biri

\footnotetext{
${ }^{19} \mathrm{Bu}$ şekilde, modern mimarlık deneyimine benzer bir yapı-mimar ilişkisinin de altı çizilir.
} 
olan kışla, her ne kadar şehirdeki diğer yapılardan farklı olarak modern mekansal bir dile sahip olsa da, malzeme ve yapım teknikleri açısından bölgesel dili kullanıyor olması ile, yapının müzeleştirilme sürecinde çevresindeki diğer yapılarla beraber şehrin tarihselliğine eklenir.

Bu bağlamda şehirdeki merkeziyetçiliğin dönüşümüne bağlı olarak modernlik algısı ile beraber aktörler, merkezsel imkanlara erişim ve buna bağlı müdahale biçimlerinin de farklılaştığ 1 ifade edilebilir. Kışlanın inşasında da, yüz yıl sonra müzeye dönüştürülmesinde de geçerli olan en önemli benzerlik, her iki inşanın da şehirde, geçmişte mevcut olmayan yeni sentakslar (mekansal nitelikler) ortaya koyuyor olmasından kaynaklanır. Kışla, bunu çevresinde inşa edilen hükümet konağı, belediye binası, meydan düzenlemelerinin birlikte ortaya koyduğu yerleşim kararları ve mekan örgütlenmesi ile yaparken, müze ise, devamındaki müze şehir vurgusu ile, bütün olarak şehir kültürü ve algısı üzerinden gerçekleştirir. 


\title{
Extended Abstract
}

\section{The Two Modern Constructions in the City of Mardin: Mardin Barracks (1887-1891) and Its Transformation into Museum (2008-2009)}

\author{
Evrim Düzenli \\ ORCID: 0000-0003-0658-2403
}

\author{
Halil İbrahim Düzenli \\ ORCID: 0000-0002-7566-5926
}

The new spatial needs arising due to the new organizations in the areas of administration, economy, military, education and so on in the Ottoman empire in the $19^{\text {th }}$ century brought about public space arrangements at the urban scale and the practices at the building scale. During this period, new types of structures that did not exist in the field of architecture in the past are observed to be emerging (Ertuğrul, 2009). Barracks structures are among these new types of buildings built to meet the need for shelter, training and protection of soldiers within the scope of arrangements in the field of military. In the study, the modernization experiences in the city of Mardin are examined through the activities of transforming the Mardin Barracks built at the end of the $19^{\text {th }}$ century and finally transformed into a museum at the beginning of the $21^{\text {st }}$ century. The most important sources about the structure which has limited literature are survey records, renovation projects and on-site evaluations. In order to determine the position of the building within the $19^{\text {th }}$ century Ottoman barracks, a barracks literature was collected, and the museum experience was evaluated through the thought and conditions of the $21^{\text {st }}$ century museum studies.

The Mardin Barracks was built between 1887 and 1891, about a century after the Kalyoncu Barracks, which was the first barracks built in the Ottoman Empire. In this context, while the Mardin Barracks means a distinctive trace of the late Ottoman centralist administration in the city, it is also a precursor of the spatial constructions waiting to be realized in the city. 
This long period from the construction of the first barracks to the construction of the Mardin Barracks can be explained by many reasons. The four reasons seem important for the city to guide its relations with the center. The first one is that resistance and hindrances formed in the center against the initial applications of modernization delayed the transfer of modernization to the country (periphery). There may be a similar resistance in the country too. For example, according to some scholars, the defeat of the Ottoman central administration against Mehmet Ali Pasha of Kavala in the Nizip War in 1839 is an important opportunity for the group of people opposing the new order in the region. There are comments suggesting that everything of European origin is intended to be eliminated with this opportunity (Aydin, vd., 2000, p.201). The second reason for the delay of the Mardin Barracks can be expressed as that the Ottomans did not have an understanding of centralism and institutional arrangements to the extent that they could achieve a rapid and total change in the country. The geographical distance between the center and the country, the limitations of communication and transportation facilities can be mentioned as the third reason. It is stated that by the beginning of the $19^{\text {th }}$ century, most of the important roads and some of the bridges became unusable and that many regions lost contact with each other and with government centers except for certain periods of the year, and that this situation negatively affected the administration, economy and social life (Çadırcl, 1980, p.153).

Finally, besides these three reasons and/or impediments in terms of centercountry relations, the unsuitability of local conditions can be emphasized. In the $19^{\text {th }}$ century in the region, in addition to Russia in the east, the frequently mentioned opposition centers such as Mehmet Ali Pasha of Kavala in Egypt and Syria, Bedirhan Bey Emirate in Cizre and Botan region, and the elements such as other principalities, tribes and notables all indicate a problem of authority and order that needs to be resolved. Therefore, the innovations intended to be brought by the Tanzimat, the struggle against Russia and Mehmet Ali Pasha of Kavala in Egypt, the dissolution of the emirates and principalities that felt independent like Bedirhan Bey, the disorder created by the tribes and the efforts to settle the tribes, the elimination of the influence of the notables in the region are intertwined with the struggles of appointed rulers against local forces. In the region where Mardin is also located, the formation of the foundation for the application of the Tanzimat was established only in 1847s (For further information, please see Aydın et al., 2000: 197-200).

Strengthening centralization in the city means taking decisions and measures to overcome the impediments mentioned above in general and realizing 
such practices in particular. The establishment of the technical infrastructure necessary for communication with the center and the creation of modern organizations are closely related to the activities of "appointed" actors and modern architectural practices in the urban area. Especially appointed administrators such as governors/pashas and modern actors such as general inspectors who began to oversee these governors at the end of the $19^{\text {th }}$ century play an important role in establishing centralism in the country. The Mardin Barracks is one of the modern-centralist architectural applications in Mardin in the $19^{\text {th }}$ century, together with the Government Building, City Hall and Girls' Art School, which were built in the same period in its immediate vicinity. They are all new types of structures that did not exist in the city in the past and they functionally increase the visibility of the state authority in the city.

The transformation of the Mardin Barracks into a museum a century after it was built is also meaningful. Such transformation means another period that represents the city's attempts to articulate into the global culture and tourism economy. This process started with the transformation of the barracks into a museum, influencing the other $19^{\text {th }}$ century buildings in its surroundings and thus converted them into new functions.

Besides the centuries-old historicity of the singular structure, the history of the city coming from paleolithic ages and its being one of the rare settlements in Anatolia that has preserved its historicity to a great extent seem to have been effective in providing the support needed for the transformation of the barracks. At this point, the museum reveals a spatial and cultural reserve for the global capital, along with its surrounding texture. The barracks built at the end of the $19^{\text {th }}$ century is essentially one of the relatively new buildings within the traditional city texture. In the context of its mass size and planimetry, it has a modern spatial language, quite different from other structures in the city. On the other hand, it provides a reference to the regional architectural style in terms of material (stone) and construction techniques (masonry). Due to these features, the barracks is the most important representative of the city's new cultural codes in the $21^{\text {st }}$ century. Depending on the transformation of centralization in the city, it can be stated that the perception of modernity has been differentiated along with the actors, access to central facilities and related forms of intervention too.

The most important similarity between the initial construction of the barracks and its transformation into a museum a century later is that both constructions reveal new syntaxes in the city that did not exist in the past. The barracks in the $19^{\text {th }}$ century, together with government mansion, town hall, and 
square arrangements built around it decipher this new syntax being made through settlement decisions and space organization. On the other hand, the museum is realized through the culture and perception of the city as a whole (with the continued emphasis on "museum city").

As a result, the two situations that can be read through the barracks structure at the end of the $19^{\text {th }}$ century and early $21^{\text {st }}$ century also offer cross-sections of the mindsets of modernity experienced in this region of Anatolia. It can be said that the two different modes of modernization have emerged in the city together with the changing "temporalities".

\section{Kaynakça/References}

CHP Mardin Halkevi (1938). 15. Cumhuriyet yılında Mardin, CHP Mardin Halkevi Yayınlarından, Sayı: 6 (İç kapak: 5). İstanbul: Resimli Ay Matbaası.

Acar, Ş., Bir, A. ve Kaçar, M. (2016). Osmanlı'da sivil mühendis yetiştirmek üzere açllan Hendese-i Mühendis Mektebi. Osmanlı Bilimi Araştırmaları Dergisi, XVII(2).

Aydın, S., Emiroğlu K., Özel, O. ve Ünsal, S. (2000). Mardin: Aşiret, cemaat, devlet. İstanbul: Tarih Vakfı Yayınları.

Aytar, İ. (2016). Sultan Abdüllaziz dönemi kışla yapılarının Çanakkale Çimenlik Kışlası örneğinde korunmasına yönelik bir yöntem önerisi. Yayımlanmamış doktora tezi. Mimar Sinan Güzel Sanatlar Üniversitesi Fen Bilimleri Enstitüsü, İstanbul.

Bashanov, M. ve Kemaloğlu, İ. (2018). Rus Genelkurmay belgelerinde II. Abdülhamit ve Osmanlı ordusu. İstanbul: Zeytinburnu Belediyesi Kültür Yayınları.

Baydaş, Ö. G. (2007). Diyarbakır ve Mardin'deki tarihi kamu yapıları. Yayımlanmamış doktora tezi. Yüzüncü Yıl Üniversitesi Sosyal Bilimleri Enstitüsü, Van.

Bekin, D. (2010). Tarihin ışı̆̆ııda Mardin. 2. Baskı. Ankara: Genpa Yayınları.

Çadırcı, M. (1980). Tanzimat Döneminde kara yolu yapımı. Ankara Üniversitesi Dil ve Tarih-Coğrafya Fakültesi Tarih Bölümü Tarih Araştırmaları Dergisi, 26.

Çataltepe, S. (1997). 19. yüzyıl başlarında Avrupa dengesi ve Nizam-ı Cedid. İstanbul: Göçebe Yayınları.

Çelik, Y. (2018). Mit ve gerçek arasında: Taksim Topçu Kışlası (Beyoğlu Kışla-i Hümâyûnu). F. Emecen, A. Akyıldız, E. S. Gürkan (Der.), Osmanlı İstanbulu III içinde (s.443-476). İstanbul: İstanbul 29 Mayıs Üniversitesi Yayınları.

Çiftçi, A. ve Seçkin, N. (2005). 19. yüzyılda İstanbul'da inşa edilen askeri yapıların koruma sorunları. Megaron Dergisi, 1 (1), 51-66.

Çiftçi, A. (2004). 19. yüzyılda Osmanlı Devleti'nde askeri mimari ve İstanbul'da inşa edilen askeri yapılar. Yayımlanmamış doktora tezi. Yıldız Teknik Üniversitesi, İstanbul. Diyarbakır Kültür Varlıklarını Koruma Kurulu arşivi.

Düzenli, E. (2012). Cizre'de modernlik ve tarihsel mekânın fenomenolojisi üzerine notlar. Arredamento Mimarlik Dergisi, 261, 71-86. 
Düzenli H. İ. ve Düzenli, E. (2019). 100 yıl önce-100 yıl sonra Mardin: Birinci Cadde ve Halkevi binası üzerinden bir modern kent okuması. Megaron Dergisi, 14 (1), 103-121.

Düzenli, H. İ. ve Taşar, E. S. (2012). Mardin'de tarih, bina ve mimarlık katmanları: 19. yy. Hükümet Konağından 21. yy. Mimarlık Fakültesine dönüşüm hikâyesi, Arredamento Mimarlık Dergisi, 254, 64-78.

Ertuğrul, A. (2009). XIX. yüzyılda Osmanlı'da ortaya çıkan farklı yapı tipleri. Türkiye Araştırmalarn Literatür Dergisi, 7 (13), 293-312.

Gedik, E. (2015). Arşiv belgelerine göre Kütahya Redif Taburu ve Redif Kışlası. Yayımlanmamış yüksek lisans tezi. Dumlupınar Üniversitesi Sosyal Bilimler Enstitüsü, Kütahya.

Gürhan, V. (2006). Hamidiye Alayları ve Mardin. İ. Özcoşar, H. H. Güneş (Der.), I. Uluslararası Mardin Tarihi Sempozyumu Bildirileri içinde (s.833-839). İstanbul: Mardin Tarihi İhtisas Kütüphanesi Yayınları.

İlban, Ö. (2015). Abdülmecid döneminde taşrada yaptırılan kışlalardan bir örnek: Tırnova Kışlası. Sanat Tarihi Yıllı̆̆ı, 24, 61-78.

İrade-i Meclis-i Vâlâ. (1891). Belge No: BH.MKT.1787/2.

Kent tarihi müzeleri ve arşivleri (2013). İstanbul; ÇEKÜL Vakfi-Tarihi Kentler Birliği Yayınları.

Sabancı Vakfı (2012). Mardin'i dinlerken: Müzeyle başlayan değişim. İstanbul: Sabancı Vakfi Yayınları.

Özen, Ö. (2013). II. Mahmud dönemi askeri ıslahat sürecinde ortaya çıan kışla yapıları ve mimari özellikleri. Yayımlanmamış doktora tezi. İstanbul Üniversitesi Sosyal Bilimler Enstitüsü, İstanbul.

Şenyurt, O. (2014). II. Mahmut dönemi Edirne Piyade Kışlası'nın tamiri için yapılan çizimlerin düşündürdükleri. Tarih ve Uygarlık İstanbul Dergisi, 6, 117-128.

Tuncer, O. C. (2008). Artuklu yapıları (yaptıran, yürüten, yapanlar). Mardin: Valiliği Kültür Yayını.

Sabancı Vakfi. (t.y). Dilek Sabancı Sanat Galerisi. 20 Ağustos 2020.http://www.sabancivakfi.org/tr/kultur/mardin/dilek-sabanci-sanat-galerisi. Adresinden erişilmiştir.

Varlık, M. B. (Yay. Haz.) (2010). Umumî müfettişler toplantı tutanakları-1936. Ankara: Dipnot Yayınları.

Yazıcı, N. (2012). Osmanlı dönemi kışla mimarisi ve Samsun Kışlası. M. Aydın, B. Şişman, S. Özyurt, H. Atsız (Der.), Samsun Sempozyumu (13-16 Ekim 2011) Bildiri Kitabı içinde (s.635-642). Samsun: Samsun Valiliği Yayınları.

Yıldırım, N. (2013). Taksim Topçular Hastanesi. Toplumsal Tarih Dergisi, 235, 44-49. 